\title{
The Implications of Zinc Therapy in Combating the COVID-19 Global Pandemic
}

This article was published in the following Dove Press journal:

Journal of Inflammation Research

\author{
Nandeeta Samad (D) \\ Temitayo Eniola Sodunke $\mathbb{D}^{2}$ \\ Abdullahi Rabiu Abubakar $\mathbb{D}^{3}$ \\ Iffat Jahan $\left(\mathbb{D}^{4}\right.$ \\ Paras Sharma $\mathbb{D}^{5}$ \\ Salequl Islam $\mathbb{1}^{6}$ \\ Siddhartha Dutta $\mathbb{1}^{7}$ \\ Mainul Haque ${ }^{8}{ }^{8}$ \\ 'Department of Public Health, North \\ South University, Dhaka, 1229, \\ Bangladesh; 'Department of Anatomy, \\ University of Ilorin, llorin, Kwara State, \\ Nigeria; ${ }^{3}$ Department of Pharmacology \\ and Therapeutics, Faculty of \\ Pharmaceutical Sciences, Bayero \\ University, Kano, 700233, Nigeria; \\ ${ }^{4}$ Department of Physiology, Eastern \\ Medical College, Cumilla, Bangladesh; \\ ${ }^{5}$ Department of Pharmacognosy, BVM \\ College of Pharmacy, Gwalior, India; \\ ${ }^{6}$ Department of Microbiology, \\ Jahangirnagar University, Dhaka, 1342, \\ Bangladesh; ${ }^{7}$ Department of \\ Pharmacology, All India Institute of \\ Medical Sciences, Jodhpur, Rajasthan, \\ India; ${ }^{8}$ The Unit of Pharmacology, Faculty \\ of Medicine and Defence Health, \\ Universiti Pertahanan Nasional Malaysia \\ (National Defence University of \\ Malaysia), Kuala Lumpur, Malaysia
}

Correspondence: Mainul Haque Unit of Pharmacology, Faculty of Medicine and Defence Health, Universiti Pertahanan Nasional Malaysia (National

Defence University of Malaysia), Kem

Perdana Sungai Besi, Kuala Lumpur,

57000, Malaysia

Tel +60109265543

Email runurono@gmail.com

\begin{abstract}
The global pandemic from COVID-19 infection has generated significant public health concerns, both health-wise and economically. There is no specific pharmacological antiviral therapeutic option to date available for COVID-19 management. Also, there is an urgent need to discover effective medicines, prevention, and control methods because of the harsh death toll from this novel coronavirus infection. Acute respiratory tract infections, significantly lower respiratory tract infections, and pneumonia are the primary cause of millions of deaths worldwide. The role of micronutrients, including trace elements, boosted the human immune system and was well established. Several vitamins such as vitamin A, B6, B12, C, D, E, and folate; microelement including zinc, iron, selenium, magnesium, and copper; omega-3 fatty acids as eicosapentaenoic acid and docosahexaenoic acid plays essential physiological roles in promoting the immune system. Furthermore, zinc is an indispensable microelement essential for a thorough enzymatic physiological process. It also helps regulate gene-transcription such as DNA replication, RNA transcription, cell division, and cell activation in the human biological system. Subsequently, zinc, together with natural scavenger cells and neutrophils, are also involved in developing cells responsible for regulating nonspecific immunity. The modern food habit often promotes zinc deficiency; as such, quite a few COVID-19 patients presented to hospitals were frequently diagnosed as zinc deficient. Earlier studies documented that zinc deficiency predisposes patients to a viral infection such as herpes simplex, common cold, hepatitis $\mathrm{C}$, severe acute respiratory syndrome coronavirus (SARS-CoV-1), the human immunodeficiency virus (HIV) because of reducing antiviral immunity. This manuscript aimed to discuss the various roles played by zinc in the management of COVID-19 infection.
\end{abstract}

Keywords: zinc therapy, microelement, immune-boosting, efficacy, COVID-19, viral infections, pneumonia, pandemic

\section{Introduction}

\section{The Global COVID-19 Pandemic}

Several mysterious and puzzling cases of severe acute respiratory disorders were reported in Wuhan's city, the capital city of Hubei Province, of the People's Republic of China in December 2019. ${ }^{1}$ In the early days, the disease was named Wuhan-pneumonia by the media after the area of the initial outbreak and based on pneumonia-like signs and symptoms. ${ }^{2}$ The World Health Organization (WHO), on 30th January 2020, declared a public health emergency with global outrage because of this novel pneumonia-related health threat. ${ }^{3}$ Recent Whole-genome sequencing to identify the causative agent reported that the causative microbes are novel coronavirus. Besides, this virus is one of the seventh fellows of the coronavirus 
family known to infect humans. ${ }^{4}$ The WHO, on 20th January 2020, named the new viral infection of 2019 as novel coronavirus (2019-nCoV). Furthermore, the WHO on 12th February 2020 publicly declared this infectious coronavirus disease 2019 (COVID-19) as a global pandemic. ${ }^{2,5-7}$ The Coronaviridae Study Group of the International Committee on Taxonomy of Viruses optedfor the viral nomenclature as "severe acute respiratory syndrome coronavirus 2 (SARS-CoV-2)", selected according to the phylogeny and taxonomy. ${ }^{8,9}$ According to WHO, as of 10:38 pm CET, 18 January 2021, there were $93,805,612$ confirmed cases of COVID-19, with a total of 2,026,093 deaths globally. ${ }^{10}$ The summary of month-wise cumulative COVID-19 cases and associated deaths in the year 2020 is depicted in Figure 1. ${ }^{10}$

\section{The Briefs on Global Pandemics}

The COVID-19 came after the previous pandemic such as 1918 Spanish flu (H1N1), 1957 Asian flu (H2N2), 1968 Hong Kong flu (H3N2), and 2009 Pandemic flu (H1N1), which caused an estimated global death toll of 50 million, 1.5 million, 1 million, and 0.3 million, respectively. ${ }^{11-21}$ The Spanish H1N1 flu pandemic of 1918 to 1919 remains the fatal global health disaster ever recorded in human history, with an estimated 40-100 million human lives lost. $^{11,22-25}$ The Spanish H1N1 flu was extremely contagious, and around $25-30 \%$ (500 million) of the global population was affected. ${ }^{26-29}$ Additionally, the average lifespan of the US national dropped by ten years. Furthermore, later pandemics caused by flu were less devastating, with the average fatality rates below $0.1 \%{ }^{30,31}$ During the Spanish flu, the severity of pneumonia among 15-34 years' age group patients was twenty times higher than among children. ${ }^{24,32,33}$ It has been further reported that Spanish flu killed many young adults who rarely suffer fatal outcomes due to influenza virus infection. ${ }^{34-36}$ The majority of patients who passed away due to Spanish flu resulted from secondary bacterial pneumonia because antimicrobial agents were not available until 1918-1919. ${ }^{37-40}$ Precisely, sudden death within five days among a large percentage of patients occurs due to acute hemorrhage, hemorrhagic pneumonia, hemorrhagic bronchitis, intra-alveolar edema, and pulmonary edema. ${ }^{37,38,41-45}$

The human influenza virus was first isolated in 1933, following a flu-like infection. ${ }^{46,47}$ During that period, paleomicrobiology science was introduced in microbiology, anthropology, history, paleontology, and archaeology. The development was to study microbial diseases associated with prehistoric material. Paleomicrobiology profoundly depends on ancient DNA (aDNA) of microbes to recognize ancient microbial diseases, virulence, evolution,

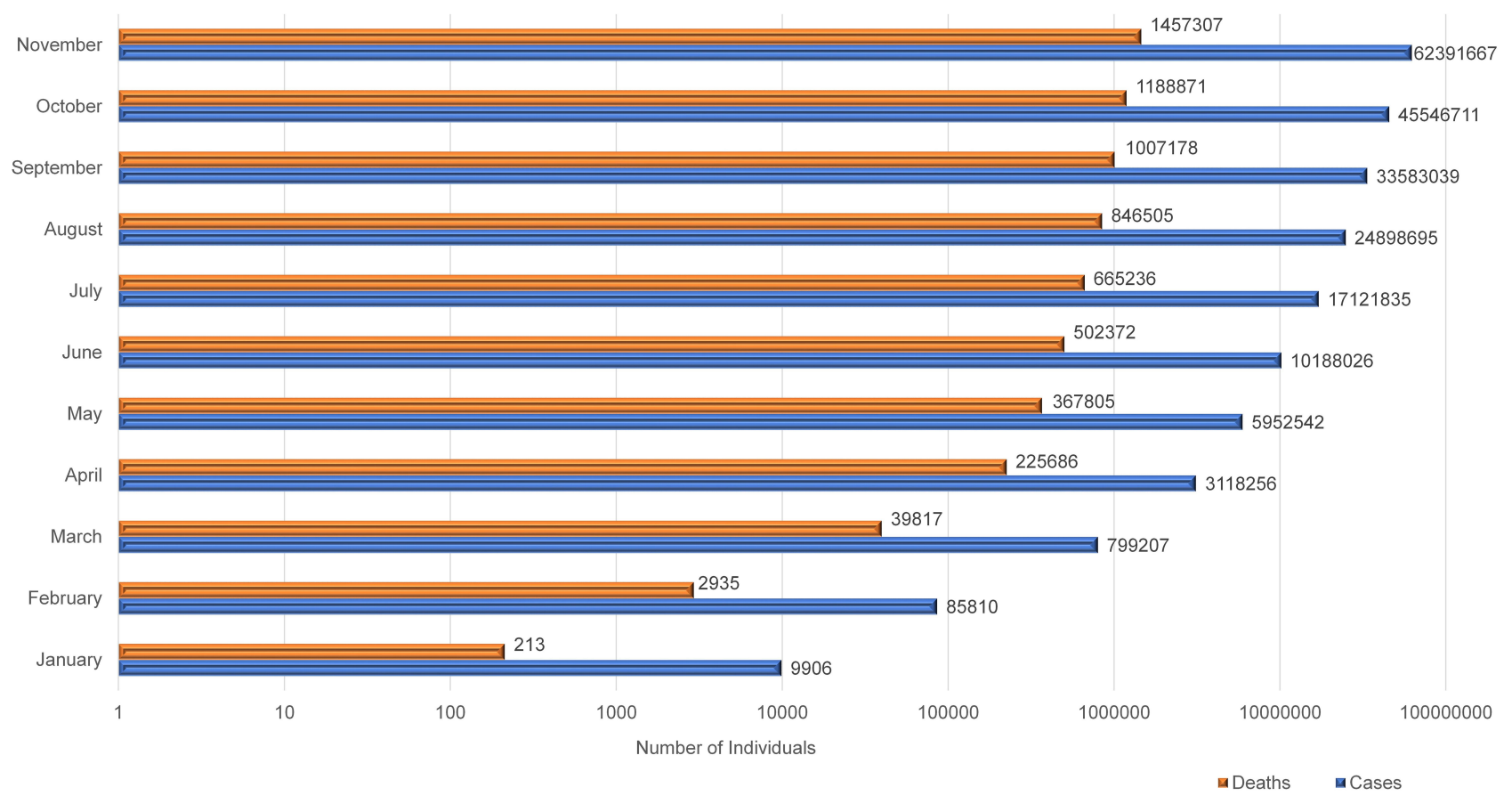

Figure I Cumulative cases and deaths associated with COVID-19 in the year 2020. 
and pathogenesis. ${ }^{48}$ The paleomicrobiology identified the pathogenic microbes of historic epidemics such as Yersinia pestis, Mycobacterium leprae, Treponema pallidum, ${ }^{49-52}$ and more importantly, the 1918 influenza pandemic. ${ }^{53-55}$ The reverse transcription-polymerase chain reaction (RTPCR) and the amplification of viral RNA sequencing techniques made it possible to detect and sequencing the 1918 causative agent. The microbe was identified as $\mathrm{H} 1 \mathrm{~N} 1$ virus from a formalin-fixed, paraffin-embedded, frozen autopsy lung tissue samples. ${ }^{35,53,56-58}$

\section{Objectives of the Study}

This review aims and scope to highlight: i. the role of Zinc Boosting, ii. the immunity mechanism of Zinc's antiviral activity, iii. Zinc's efficacy and safety in combating COVID-19 and iv. to conclude and give prescribers and policymakers direction.

\section{Materials and Methods}

Although the literature exploration is a mandatory segment for systematic review and meta-analysis, ${ }^{59-61}$ nevertheless, multiple critical studies regarding narrative review advocated incorporating a section about search strategies. ${ }^{62-64}$ Thereby, this manuscript incorporates the section of materials and methods. The literature search was not systematic but was based on the Baethge et $\mathrm{al}^{62}$ strategies and performed using four core bibliographic databases (Google Scholar, PubMed, Scopus, and China National Knowledge Infrastructure). We were aware of the strength of the web of science but could not include because of financial constraint as the current manuscript did not obtain any financial support. The authors relied principally on open access journals and access to journals granted by the Universiti Pertahanan Nasional Malaysia (UPNM), the National Defence University of Malaysia (UPNM), Kuala Lumpur, Malaysia, and North South University, Dhaka-1219, Bangladesh. Articles those not available in full-text or not written in English were excluded. The only nonEnglish papers utilized refer to the history of zinc therapy. The study was conducted between early June 2020 and late November 2020. The search terms used include "Zinc Therapy, Microelement, Therapeutic Potential, ImmuneBoosting, Efficacy, COVID-19, Viral infections, Pneumonia, Pandemic". This is followed by the snowballing of references cited by critical articles. We had included all types of peer-reviewed articles published in English. Subsequently, after the first-round search, additional references were identified through labor-intensive search using the selected references. The present article's narrative nature, both recent and older publications with historical significance, were incorporated.

\section{Zinc Role in Human Health}

Zinc is essential in maintaining human physiology and was first identified in an Iranian patient in $1961 .^{65}$ The patient was suffering from growth impedance, hypogonadism, dwarfism, hepato-splenomegaly, rough and dry skin, geophagia, and severe iron deficiency anemia. ${ }^{66} \mathrm{He}$ was a $21-$ year-old agriculturalist whose food was limited to less nutritious hand-made bread, potatoes, and milk. ${ }^{65,66}$ The essentiality of zinc among microbial systems, ${ }^{67}$ experimental animals, ${ }^{68}$ higher plants, ${ }^{69}$ and animals including chickens $^{70,71}$, and pigs $^{72}$ were identified much earlier in 1869, 1934, 1926, and 1950-1960, respectively. Subsequently, among humans, zinc deficiency was associated with hypogonadism/dwarfism, ${ }^{66,73}$ an autosomal recessive defect known as acrodermatitis enteropathica (AE) ${ }^{74,75}$ and limiting-growth among healthy children. ${ }^{73-76}$

Zinc is a trace element; however, it remains a vital micronutrient for maintaining cellular physiology such as vision, taste perception, cognition, cell reproduction, growth, and immunity. ${ }^{74-82}$ Zinc deficits dampen equally innate and adaptive immune responses. ${ }^{83}$ Zinc deficiencies are evident by oxidant stress, increased inflammatory process, and life-threatening situations, as well as premature cell death at the cellular and sub-cellular levels. ${ }^{84,85}$ It has been reported that over 300 regulatory enzymes require zinc for their inhibition-activation processes. $^{65,86,87}$ Furthermore, the sepsis process's signal transduction pathways are positively correlated to zinc deficiency. ${ }^{84,88}$ Nuclear Factor Kappa B (NF-kB), a transcription factor known as the principal controller of the proinflammatory process, especially in infectious diseases, is also affected by zinc deficiency. ${ }^{83,89}$ Additionally, NF- $\mathrm{kB}$ controls several characteristics of innate and adaptive immune purposes. $^{90}$ Moreover, common pathogenic microbes, including viruses, activate $\mathrm{NF}-\kappa \mathrm{B}$, are remain raised among infected individuals. ${ }^{91,92}$ High NF- $\mathrm{BB}$ is related to marked pro-inflammatory effects, and high death rates among infected patients, especially aggressive infections, were instigating sepsis and septic shock, which could minimize with dietary zinc. ${ }^{93,94} \mathrm{NF}-\mathrm{kB}$ inhibits the formation of superoxide dismutases (SODs). Low-level SODs promote the synthesis of reactive oxygen species (ROS) due to the inflammatory process. ${ }^{95}$ Multiple studies reported that a low level of zinc weakens SOD activity 
and favors the formation of a high amount of ROS, leading to irreversible damaging effects within the cell. ${ }^{96-98}$ Although zinc is an inactive redox metal; nonetheless, zinc possesses indirect antioxidant properties by its ability to interact with sulfur. ${ }^{99,100}$ Zinc-Sulphur bonding is reversible and controls enzyme catalysis mechanisms within the cell; thereby, intercellularly zinc binds strongly with redox-active and converts to the redox-inert zinc ion. In that way allows zinc to promote in shielding oxidant environment. ${ }^{99,101}$ Overall, zinc subsidizes to preserve the cell redox equilibrium through five different strategies. These include i. the synchronization of oxidant synthesis and metal-induced oxidative impairment; ii. the potential relation of zinc with sulfur in protein cysteine clusters; iii) zinc role in rummaging oxidants; iv. its role in glutathione metabolism and the comprehensive protein thiol redox status; and v. its direct or indirect role in controlling redox signaling. ${ }^{99}$ Therefore, low-level intracellular zinc decreases the capability to endure exceedingly oxidant settings commonly occurring in severe infectious diseases. ${ }^{102-104}$

\section{Zinc and Viral Infection}

Zinc is an essential trace element that significantly impacts health, especially in maintaining immune physiology, growth, and development. Zinc is also considered an agent of antiviral immunity and an enhancer of both inherent and acquired immunity. ${ }^{105,106}$ Earlier studies reported that high dose zinc consumption has effectively boosted patients' immune systems with several viral diseases, including torquetenovirus (TTV), common cold (rhinovirus). ${ }^{107-109}$ Apart from its effect on cellular division, differentiation, and rapid growth in humans, its role in preventing common cold and viral infections is underscored to date. ${ }^{110}$ Increased susceptibility of viral infections has significantly been associated with zinc deficiency in the human body. Zinc-deficient individuals are more prone to severe viral infections like HIV and devastating outcomes in viral and bacterial co-infections. These include influenza-MRSA bacterial superinfection, S. aureus infections, and many more. ${ }^{111,112}$ In light of the sudden onset of the COVID-19 global pandemic, there has been an increasing interest in searching for potential protective and therapeutic measures necessary to curb the uncontrollable spread of this virus. ${ }^{13,114}$ Respiratory system pathology and oxygen saturation have improved with zinc supplements in clinical trials. ${ }^{111,115}$ Notably, the elderly population that usually develops acute respiratory syndrome has lower serum Zinc levels. ${ }^{116-118}$ Similarly, $80 \%$ incidence of pediatric pneumonia is associated with low serum zinc levels. ${ }^{117}$ However, in the case of COVID19, natural immunity and resistance capacity, in-built in children, are likely to categorize them into less vulnerable groups. ${ }^{119,120}$ Since no approved effective treatment is yet available to minimize the current global pandemic's intensity, micronutrients like zinc, for its immune-boosting effect, and the antiviral mechanism is presumed to combat COVID-19 to some extent. ${ }^{105,106,121,122}$ Although studies to date have rarely focused on clinical data and the number of randomized control trials to test the immunity-boosting effects of zinc supplement, and certain speculations have supported the fact that the modulation of a person's zinc status will most likely create a positive influence in the therapy of COVID-19. ${ }^{105,117}$

\section{Anti-Viral Effects of Zinc as a Therapy for COVID-I 9}

Even though available data on the direct effect of zinc and COVID-19 is still rare, its antiviral effect has been proven against other viral diseases. This pattern was evident on viral infections through several modulation pathways such as fusion, replication, viral protein translation, viral particle entry, especially those involving respiratory system pathology. ${ }^{105,118,121,123,124}$ A possible clarification for the relevance of zinc in the treatment of COVID-19 conditions has been attributed to its immunomodulatory effect, antiviral property, as well as its ability to regulate the inflammatory response. ${ }^{112,125,126}$

The possible mechanisms by which zinc might be effective in the therapy of COVID-19 are based on the previous evidence with other common viral infections and limited experience with COVID-19 [Figure 2]. Zinc has been found to refine and improve cilia's morphology and increase its length and beating frequency. ${ }^{127}$ It is also considered as a membrane stabilizer and helps to maintain cytoskeletal integrity. ${ }^{128}$ The membrane tight junction proteins like ZO-1 and claudin-1 expression are enhanced to strengthen the respiratory epithelium's barrier function. ${ }^{129}$ Enhanced antioxidants' functioning of respiratory epithelium and the suppression of caspase activation and apoptosis further protect the respiratory epithelial lining. ${ }^{128}$ Zinc is proposed to prevent viral entry and block its replication by inhibiting the RNA dependent RNA polymerase (RdRp) of the virus. ${ }^{121,130}$ Zinc also minimizes the Sirtuin 1 (SIRT-1) induced angiotensin-converting enzyme 


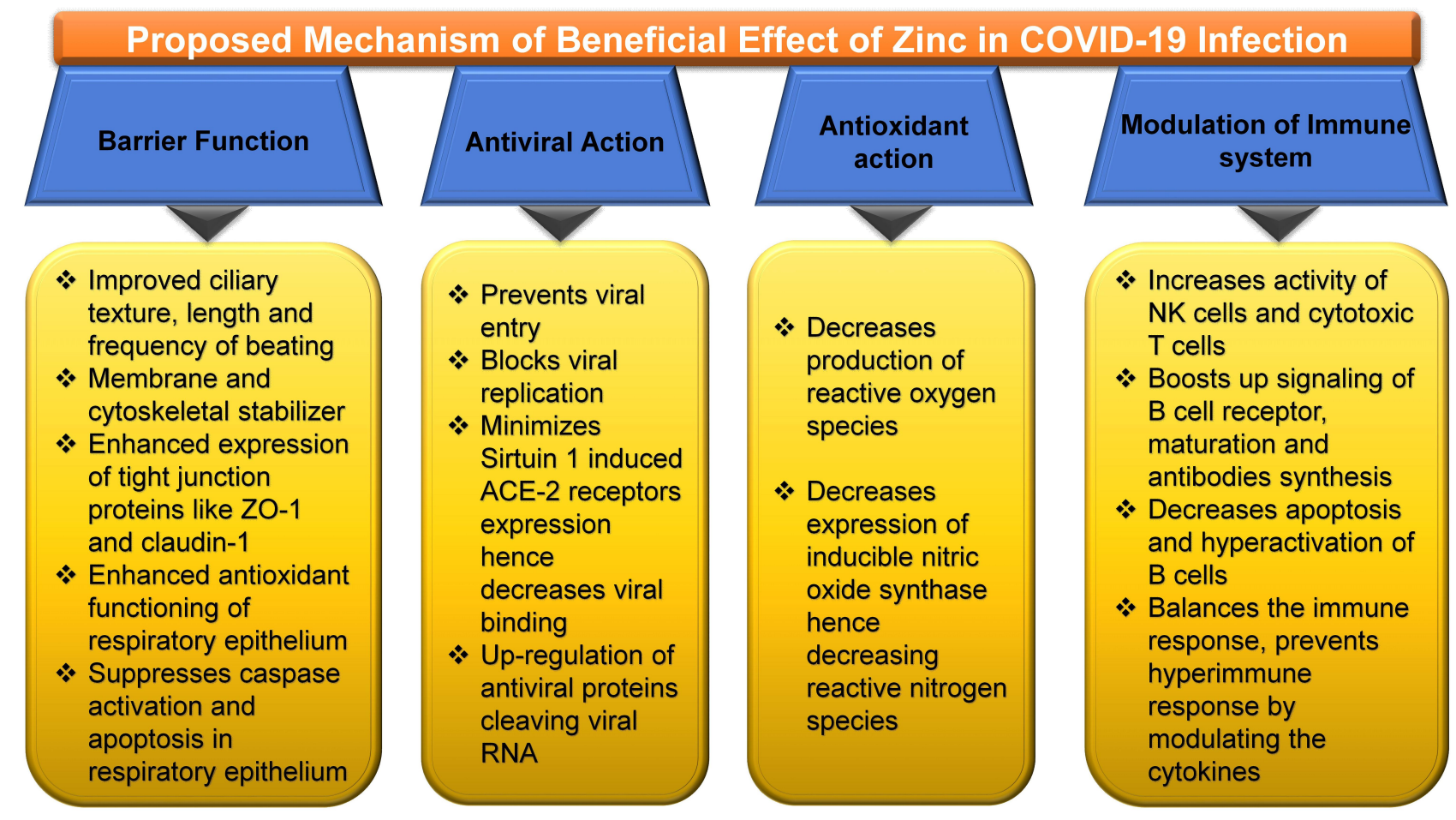

Figure 2 Zinc and its plausible effectiveness in COVID-19.

Notes: Barrier function, ${ }^{127-129}$ antiviral, ${ }^{105,118,121,123,124,130,131,133}$ antioxidant, 134 immunomodulatory. ${ }^{131-139}$

Abbreviations: ACE-2, angiotensin-converting enzyme 2; NK cells, natural killer cells; ZO-I, zonula occludens-I.

2 (ACE-2) receptors expression, decreasing the probability of Viral binding ACE2 receptors. ${ }^{121,131}$ Zinc also modulates the immune system and increases the production of IFN $\alpha$ production by leucocytes. ${ }^{132}$ Zinc, by increasing the levels of IFN $\alpha$ production, indirectly increases the synthesis of antiviral proteins like latent ribonuclease and protein kinase RNA-activated, which can degrade viral RNA. ${ }^{131,133}$ Zinc has a well-known antioxidant action with reduced reactive oxygen species production and reactive nitrogen species. ${ }^{134}$ It also exhibits anti-inflammatory action by inhibiting NF- $\mathrm{kB}$ signaling leading to decreased production of proinflammatory cytokine. ${ }^{135-137}$ Zinc has been found to increase Natural Killer cells' activity, Cytotoxic T cells activity, and B Cell Receptor Signaling, along with increased production of antibodies. It also modulates regulatory T-cell functions preventing hyperactivation of the immune system's hyperimmune response by modulating and balancing the cytokines. ${ }^{138,139}$

Multiple comprehensive reviews on this subject matter through in-vitro experiments have demonstrated that $\mathrm{Zn}^{2+}$ ions, combined with $\mathrm{Zn}$ ionophore pyrithione, are instrumental in inhibiting SARS-coronavirus RNA polymerase activity, mainly by reducing its replication, hence prevent common colds. ${ }^{130,140}$ These findings have not only pointed its probable value in the treatment of COVID-19 but has specifically been linked to chloroquine (CQ) efficiency. This is due to its antiviral ability as zinc ionophore, which increased the influx of $\mathrm{Zn}^{2+}$ ions into the cell.130,141,142 Nevertheless, the observations show that even though this ideology has positive prospects, there is a need to investigate further the mechanism of zinc's antiviral activity. ${ }^{142}$ Additionally, a comprehensive study by Guastalegname and Vallone ${ }^{143}$ showed that the use of zinc supplements without CQ could produce positive outcomes with the exclusion of the side-effects that a CQ treatment could cause.

Generally, the role of Zinc as a stimulant of antiviral immunity coupled with its negative repercussions if deficient in the elderly persons or individuals with certain metabolic diseases like diabetes, obesity, or cardiovascular diseases has buttressed several hypotheses that claimed the use of zinc compounds might serve as an adjunct therapy in COVID-19 treatment. ${ }^{105,125,144-146}$ However, some critics have challenged its consumption rate notwithstanding the positive effects of using Zinc. It was suggested that 25-50 mg zinc per day is affordable and would not cause adverse effects than a higher intake of 200 to $400 \mathrm{mg}$ per day, triggering epigastric pain, lethargy, vomiting, and 
nausea, and fatigue. ${ }^{147,148}$ Interestingly, zinc supplementation has been influential in reducing the replication of influenza virus, reduction of hepatitis in $\mathrm{HCV}$ infected patients, enhancement of response to antiviral treatment, improvement of both cutaneous and genital warts which are induced by human papillomavirus (HPV), and most notable is the significant reduction of prevalence in pneumonia, especially in developing countries. ${ }^{149-152}$ Overall, these observations strengthen the fact that adequate zinc balance is essential to protect an individual from microorganisms, including viral infections. An uptake of up to $40 \mathrm{mg}$ per day of zinc as recommended will likely reduce the potential threat of the COVID-19 pandemic, resulting from the rise in the host resistance to viral infections. The efficacy, tolerability, and safety of combining zinc with CQ remain a viable option in conquering COVID-19. ${ }^{111}$

\section{Zinc, Its Immune-Boosting Effects, and Association with Pneumonia}

Previous studies have acknowledged the importance of zinc as a dietary trace mineral capable of influencing the immune system regarding zinc relevance to immunity. ${ }^{112,153,154}$ Dietary trace minerals are vital in regulating, multiplication, growth, and differentiation of lymphocytes and leukocytes, functioning as the body's immune system. ${ }^{132}$ Moreover, it is often noted that zinc plays a significant role in the activation and inactivation of numerous enzymes and co-enzymes crucial in cellular functions such as DNA synthesis, RNA transcription, and energy metabolism. ${ }^{153,154}$ These findings broadly support the work of earlier studies that have ascertained that any disruption in an individual's zinc contents will undoubtedly affect their immune system responses. ${ }^{84,155-157}$ This alteration gives rise to an increased predisposition to infectious and inflammatory conditions that include acquired immune deficiency syndrome, pneumonia, measles, malaria, tuberculosis, and others. ${ }^{84}$ Evidence has shown that an adequate level of zinc in individuals stimulates an increase in immune reactivity. An insufficient zinc supply level may be a potential risk to these individuals' upper and lower respiratory tracts in the same way. ${ }^{112}$ Furthermore, earlier studies have shown that the prevalence of respiratory tract infections in children and adults has been linked to their Zinc uptake levels. ${ }^{112,158,159}$ From the estimated decline in zinc incidence globally (up to $17 \%$ ), its impact on public health is considered an issue of grave concern. ${ }^{160}$

According to the research, a decline in zinc levels could affect B-cells' development, reduce immunoglobulin production, increase infection rate, and most notably increase death rates. ${ }^{161-163}$ Despite this understanding, a specific category of people, such as infants (pre-term) and elders, are considered more vulnerable to having a reduced level of zinc and its adverse effects. ${ }^{164}$ The risk factors associated with COVID-19 include aging, immune deficiency, diabetes, obesity, and atherosclerosis, closely associated with zinc deficiency. ${ }^{165-168}$ It is imperative to note that these findings, alongside various evidence on zinc's role in immune function, have instigated interest in zinc's possible potential benefit for preventing and treating the common cold and COVID-19 infection. According to a review published by Singh and Das, ${ }^{169}$ zinc supplementations produced a significant reduction in the duration of the common cold and the incidence rate of common cold development. This distinction is further exemplified in studies that have revealed the connection between zinc status and respiratory syncytial virus (RSV) infection. This could be explicitly found in cases of significantly low blood zinc levels amongst children with RSV pneumonia. ${ }^{12,170-172}$ Several surveys conducted have claimed that zinc consumption is likely to reduce the intensity of COVID-19 infection due to its antiviral properties; it also helps to alleviate respiratory tract infections. ${ }^{105,173,174}$ It is noteworthy, researchers have found that the level of ionic zinc present in oral and nasal mucosa positively correlates with the duration of the common cold in that person. This implies that a higher dose of zinc uptake demonstrates a reduction in common cold duration, and a lower amount produces otherwise. ${ }^{173-176}$ It is also important to note the similarity between the route by which COVID-19 enters the body, such as lungs, and that of the common cold. However, there is a need for further investigations (clinical validation), which can ascertain if the availability of a particular concentration of zinc at the site of infection will cause a decline of COVID-19 disease or not. ${ }^{123}$

\section{Evidence of Zinc's Effectivity on COVID-19, Toxicity, and Prospects of Oral Zinc Therapy}

There are quite a few published studies that illustrate the efficacy of zinc therapy in managing COVID-19 patients. ${ }^{177-179}$ Many individuals globally consume zinc tablets, vitamin $\mathrm{C}$, and $\mathrm{B}$ because of immune booster effects and combating COVID-19 and its antiviral. ${ }^{180,181}$ However, a recent pre-print United States-based retrospective analysis utilizing electronic medical records 
found that patients treated with hydroxychloroquine and azithromycin with the addition of zinc sulfate had a higher recovery rate. ${ }^{182}$ Interestingly, additional input of zinc sulfate was claimed to be associated with lower mortality rate, need for hospice care, and less invasive ventilation requirements. However, this association remained null when observed among Intensive Care Unit (ICU) patients. ${ }^{182}$ These associations should further be studied in different clinical trials and laboratory tests to provide more robust shreds of evidence. Preventive measures by zinc supplement should be accompanied by a standard of care among COVID-19 patients. Henceforth more double-blind controlled clinical trials should be conducted to confirm the effectiveness. Generally, zinc should be prescribed as an optimal zinc supplement. This is because the recommended intake depends on particular conditions or specific illnesses. Acute zinc toxicity could lead to nausea, vomiting, abdominal cramps, persistent diarrhea, and other gastrointestinal abnormalities like hematemesis, haematuria, and renal syndromes. At the same time, chronic overdose manifests as sideroblastic anemia, neurological disorders, granulocytopenia, myelodysplastic syndrome, and copper deficiency. ${ }^{183-185}$ Furthermore, there have been no reports of deaths or significant life-threatening adverse drug reactions related to zinc supplementation. ${ }^{186}$ Therefore, both preventive and therapeutic doses should be determined for COVID19 patients considering age, gender, and comorbidity to avoid further consequences. As there is some zinc-related toxicity; thereby, an individual should seek health professional advice before zinc supplementation. However, these supplementary medicines are sold as over-the-counter products without prescription. Oral zinc supplements are likely to be recommended in arresting the burden of COVID-19. This is due to its oral bioavailability and because zinc participates in protecting the body from viral and bacterial infections and improving immunity. ${ }^{126}$ Therefore, vigorous clinical studies should commence urgently to validate the therapeutic efficacy of oral administered dose and investigate its limitations. It is noteworthy, although SARS-CoV-2, influenza, and rhinoviruses employ distinct cellular receptors, angiotensin-converting enzyme-2 (ACE2) present in the oral cavity and upper airway's epithelium further suggests reasons to initiate oral zinc therapy. ${ }^{187}$ Unless a comprehensive study is conducted with scientific approval of oral zinc therapy for COVID-19 patients, nobody should take it as self-prescribed. This is to avoid overdose leading to substance abuse and worsen the patient's condition. ${ }^{187}$ It should also be investigated and see if the elevated level of oral zinc helps combat SARS-CoV2 and mitigate the intensity, complications, and duration of COVID-19. All efforts should continue until the globally approved vaccination process is concluded. The nutritional therapy, particularly zinc considering its antiviral and immunity-boosting potency, should be further investigated in order to recognize its possible role in prophylactic as well as an adjuvant during treatment against SARS-CoV-2.

\section{A Brief Overview Regarding Various Zinc Ionophores and Cytokine Strom}

Several drug molecules such as hydroxychloroquine, CQ, pyrithione, hinokitiol ( $\beta$-thujaplicin), and dietary supplements [quercetin and epigallocatechin-gallate (ECGC)], act as $\mathrm{Zn}$ ionophore. Thereby, it facilitates Zn's entry across a cell's lipid membrane and considerably increases Zn's intracellular levels, particularly in the endosomallysosomal section. ${ }^{142,188-191}$ Raised concentration intracellular $\mathrm{Zn}^{2+}$ demonstrates antiviral activity, including COVID-19 involving three distinct antiviral mechanisms of action [Figure 3]. 142,190,192

The exact mode of action of hydroxychloroquine remains elusive to date. ${ }^{193}$ Several ongoing studies are utilizing various updated scientific approaches to accomplish a better understanding of antiviral pharmacodynamics. ${ }^{194}$ Those hitech scientific tools comprise computational biology, ${ }^{194}$ Immunology, ${ }^{195,196}$ Structural biology, ${ }^{197,198}$ Modern molecular medicine, ${ }^{199,200}$ Synthetic biology, ${ }^{201,202}$ and big datadependent public health research. ${ }^{203,204}$ Viral access into the human host cells is perhaps the most imperative factor regarding viral infection. Acidification endosomes and lysosomes remain the critical issue for membrane fusion and entry of enveloped viruses into the cell. Moreover, several enzymes disrupt the viral unit to release infectious nucleic acid. ${ }^{193,205,206}$ Then again, CQ, Hydroxychloroquine (HCQ), being a weak base, accrues within these acidic vesicles, increases the $\mathrm{pH}$, and stops the $\mathrm{pH}$-dependent endosomemediated viral entry. Additionally, HCQ or its other active zinc-derivatives bind to the host cell surface gangliosides via sialic acids and restrict attaching the viral S protein and, in that way, impedes the infection of the virus. ${ }^{193,205}$ This mechanism of action of HCQ ultimately disrupts the viral attachment and supports as a repositioned drug to treat 


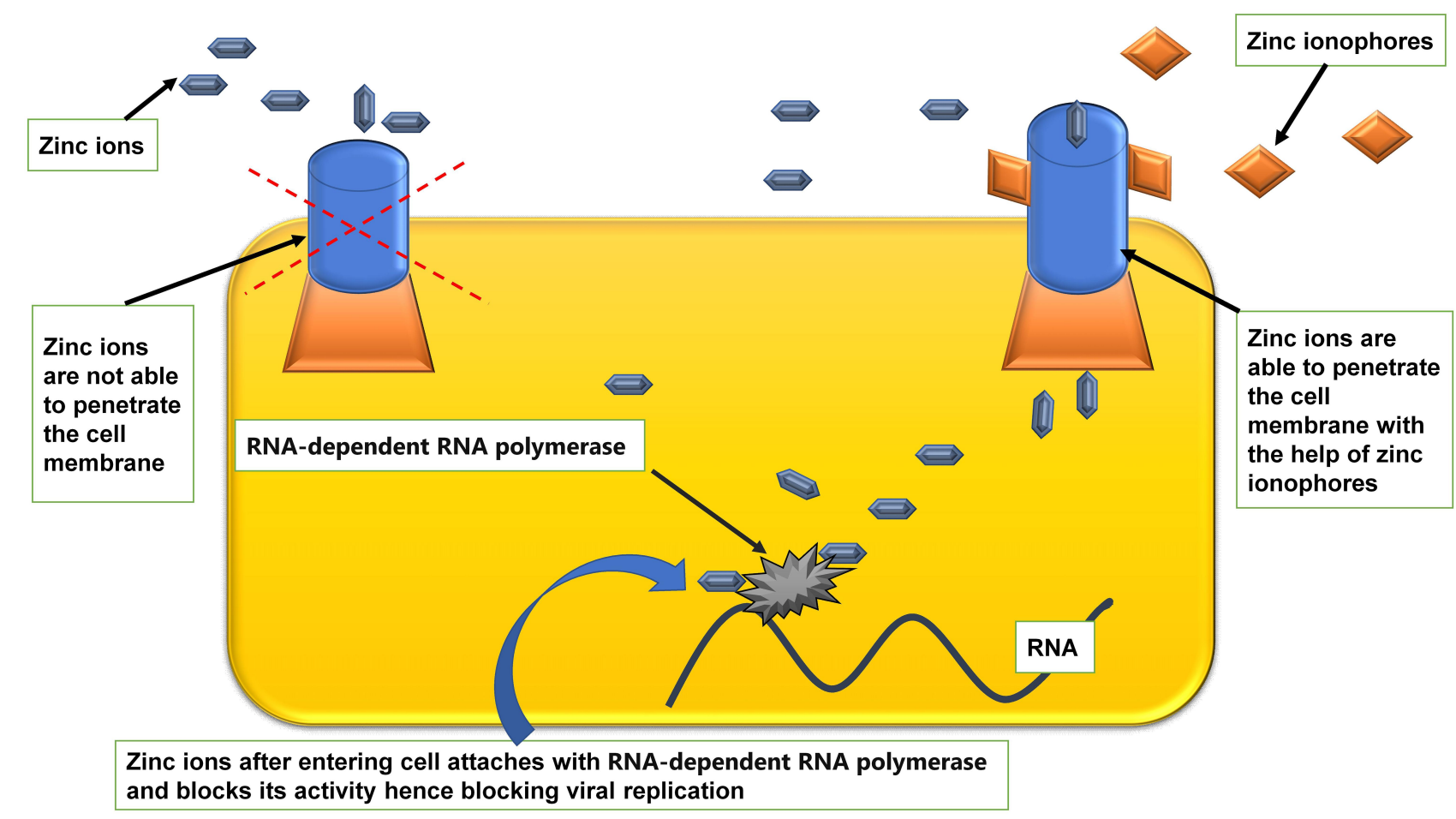

Figure 3 Facilitatory mechanism of zinc ionophores in entry of zinc into cell. ${ }^{130,|140-142,| 88-191}$

patients infected with SARS-CoV-2. Among severe cases of COVID-19, especially in ICU, minimizing pro-inflammatory cytokines is an urgent need..$^{207-209}$ Multiple studies reported that both HCQ and CQ possess potential in curtailing proinflammatory cytokines (IL-1 $\beta$, IL-6, GM-CSF, NF- $\kappa$ B, etc.) effects. $^{210-215}$ These proinflammatory cytokines are a potentially troubling issue in the management of COVID$19^{216-218}$

\section{Zinc's Role in the Renin-Angiotensin System Mediated Bradykinin Storm in COVID-I 9}

The severe cases of COVID-19 often necessitate ICU admission. It has been documented that among these patients, the concentrations of granulocyte-colony stimulating factor (G$\mathrm{CSF}$ ), interferon gamma-induced protein 10 (IP10), monocyte chemoattractant protein 1 (MCP1), macrophage inflammatory protein 1 alpha (MIP1A), and tumor necrosis factoralpha (TNF $\alpha$ ) are higher as compared to patients who do not require ICU. ${ }^{219,220}$ Additionally, specific chemokines like interleukin-2 (IL-2) receptor, interleukin-6 (IL-6), interleukin-8 (IL-8), interleukin-10 (IL-10), and TNF $\alpha$ were found raised in severe cases with COVID-19 than patients who had improved. $^{220-222}$ These immunologic manifestations due to unrestrained cytokine release among COVID-19 patients, leading to grave clinicopathological expression is coined as Cytokinin Storm. ${ }^{223}$ Abandoned cytokine response among COVID-19 cases frequently go together with more immune cell activation, including T helper 17 cells (Th17) differentiation from CD4+ lymphocytes. ${ }^{224,225}$ In reality, augmented Th17 responses were stated in MERS-CoV, SARS-CoV, and SARS-CoV-2. 224,226-228

Multiple studies have reported that COVID-19 severe cases recurrently develop arrhythmia and unforeseen cardiac failure correlated with hypokalemia because of high serum bradykinin levels. ${ }^{208,229-238}$ Moreover, several COVID-19 symptoms such as myalgia, fatigue, nausea, vomiting, diarrhea, anorexia, headaches, and decreased cognitive function are strangely similar hyper-bradykinin settings develop due to vascular hyper-permeabilization leading to angioedema. ${ }^{238-240}$ Thereafter, Garvin et al concluded that the "pathology of COVID-19 is likely because of Bradykinin Storms rather than cytokine storms". 238 Bradykinin is a proinflammatory peptide synthesized from an inactive pre-protein kininogen through stimulation by the serine protease kallikrein (KLK). ${ }^{241,242} \mathrm{KLK}$ is characterized by a group of serine proteases (KLK1KLK15) found in several tissues; KLKB1 is usually found in the pancreas and is responsible for plasma kallikrein. $^{243,244}$ Furthermore, bradykinin serum level is 
dependent on the Renin-Angiotensin System (RAS). ${ }^{245,246}$ $\mathrm{Zn}^{2+}$ is divalent cations and inhibits serine proteases (KLK4, KLK5, KLK7, KLK2) by binding with the active sites. $^{247-252}$

\section{Role of Micronutrients, Vitamins, and Other Trace Elements in the Management of COVID-I 9}

To reduce the global COVID-19 burden, enhancing immunity by maintaining functional nutritional status is desirable, and more importantly, such enhancement is achievable by consuming a balanced diet. .... with an active lifestyle can boost the immune responses to combat the SARS-CoV-2 infection better. ${ }^{253}$

Adequate nutritional level promotes better immune status regarding microbial diseases, including viral infection. ${ }^{254}$ Several micronutrients, particularly vitamins A, C, D, E, B2, B6, and B12, folic acid, iron, selenium, zinc, arginine, glutamine, omega-3 fatty acids, and polyphenols, are of critical necessity for the development of good immune status. ${ }^{255,256}$ Selenium is a crucial component of the enzyme system of our body and a to a great extent, deficiency of selenium leads to improper functioning of the cellular immunity and increases the probability of oxidative stress which can further amplify the risk of viral genome mutation, enhanced pathogenicity and difficulty in treating the infection hence growing mortality. ${ }^{254,257,258}$ Although evidence is limited yet early experience in COVID-19 patients shows that adequate selenium levels were associated with a better recovery rate than COVID-19 patients from the cities or high selenium levels had a high cure rate and low mortality as compared to low selenium levels areas. ${ }^{259}$ The effectiveness of selenium in viral infections is supported by previous poliovirus infection, HIV, and epidemic hemorrhagic fever. ${ }^{260-262}$ Copper is a crucial element for an intact and robust immune system, and its deficiency has been seen to be associated with an increased rate of infections. ${ }^{263}$ Copper has been found to modulate neutrophil, macrophage, and functioning of natural killer cell activity. Evidence shows that copper enhances T lymphocyte functioning and proliferation and helps synthesize IL-2, hence improving immunity. ${ }^{264}$ Previous evidence reveals that copper or ceruloplasmin deficiency leads to improper copper metabolism in the body and can increase the probability of developing various bacterial infections, diarrhea, recurrent respiratory tract infections, and even pneumonia. ${ }^{265-267}$ Iron as an element is a well- established modulator for the immune system's proper functioning. ${ }^{268}$ On the contrary, it has been seen that the activity of SARS-CoV2 and its viral replication needs iron, and now iron chelators are being considered as a therapy in COVID-19 [Figure 4]. ${ }^{269,270}$

Apart from these elements, contemporary lifestyles often encourage families to consume fast food (junk food) because of there easy availability. These foods frequently do not possess essential nutrients. ${ }^{271}$ Multiple studies have been reported that infectious diseases often affect individuals with deficiencies in essential micronutrients and trace elements. ${ }^{272-274}$ Moreover, research studies reported that the immune physiology could be restored to the normal level by consuming a balanced diet and, if necessary, supplementing micronutrients and trace elements. ${ }^{274,275}$ In this manner increases resistance to infection and supports quicker recovery from infectious diseases by reducing both inflammation and oxidative stress triggered by several reasons. ${ }^{255,272,274,275}$ By this means, micronutrient insufficiencies have been identified as an international public health concern. ${ }^{258,276,277} \mathrm{~A}$ recent study by Darnton-Hill reported that selenium, iron, potassium, sodium, calcium, magnesium, folic acid, copper, and zinc play an important role in improving the immune physiology and patient recovers earlier and decrease hospital stay among COVID-19 patients. $^{258}$ In support of that, several studies across the world advocated the importance of a balanced diet with relevant nutrients and trace elements as an extenuation approach to build robust immune physiology to fight back the COVID-19 pandemic. ${ }^{254,268,278-280}$

\section{Conclusion}

COVID-19 is a formidable challenge to the entire current world as there is no specified antiviral treatment possibility to date, thereby, preventive and control measures, or potent medicine available to fight the disease back. The host immune system plays pivotal roles against COVID-19 disease progression, similar to many other viral infections. The micronutrient zinc was found to strengthen both the innate and adaptive immune cells. The antiviral effects of zinc have been reported in several viral diseases by boosting the immune systems. Furthermore, zinc augments the normal physiological process by facilitating epidermal, gastrointestinal, central nervous, skeletal, and reproductive systems in the human body. Altogether, zinc inhibits the virus's entry in the human cell, the viral 


\section{Selenium}

* Essential co-factor in the enzyme systems *Deficiency

- Leads to improper functioning of the cellular immunity and increased oxidative stress

- Increased risk of mutation in viral genome, surged pathogenicity and increased mortality in patients

\section{Copper}

* Essential for potent and robust immune system

* Modulates the activity of neutrophil, macrophage and natural killer cells

* Modulates T cell activity and its proliferation

*Helps in synthesis of IL-2

* Deficiency-Increased rate of infections (bacterial infections, diarrhea, respiratory tract infections)

\section{Essential Micronutrients and Possible Effectiveness in COVID-19}

Iron

* Modulator of effective functioning of immune system

* SARS-CoV-2 needs iron for its replication hence iron chelation might prove effective
Miscellaneous micronutrients

* Vitamin A, C, D, E, B2, B6, B12 and folic acid

* Arginine, glutamine, omega-3 fatty acids, and polyphenols

* Electrolytes like Potassium, sodium, calcium and magnesium

Figure 4 Potential micronutrients effective in COVID-19. Selenium, ${ }^{254,257-259}$ copper, $^{263-267}$ iron, $^{268-270}$ misc. $^{258,272-274}$

replication process, protein transformation, polyprotein handing out, viral interaction with human cell, and viral uncoating. Consequently, this study suggests that zinc supplementation as an adjunct to other medications could provide dual advantages in preventing and managing COVID-19. However, well-designed doubleblind controlled clinical trials must assess its long-term safety and effectiveness as affordable medicines.

\section{Recommendations}

Further studies are strongly recommended to assess Zinc's effectiveness as an enhancer in using CQ for COVID-19 treatment. SARS-CoV binds angiotensinconverting enzyme 2 (ACE2) on pneumocytes using its spike (S) proteins. ${ }^{281,282}$ Virus enters the susceptible host cell through endocytosis and mediates both replication and transcription. Different metallic ions are known to stimulate viral replicating enzymes as co-factors. The roles of Zinc should be checked as co-factors for SARSCoV-2. Roles of Zinc for facilitating $T$ cells in the Immune System need to be evaluated in light of COVID-19. Zn was found to provoke the immune system, especially the Natural Killer (NK) cells, ${ }^{83,283}$ that usually play antiviral roles by releasing perforin. ${ }^{284}$
Further detailed research to elucidate the functions of Zinc in these areas is recommended. Overall, Zinc roles should also be investigated for all other innate adaptive human antimicrobial peptides and proteins, ${ }^{285,286}$ potentially for COVID-19 treatment.

\section{Professionals Annotation}

According to the WHO, the urgent need to address the global outburst caused by the coronavirus necessitated a worldwide state of a public health emergency. ${ }^{2,5-7}$ With no regard for status or class, the COVID-19 pandemic remains a substantial threat that disrupts both high-income-countries and low-middle-income countries globally. Despite its negative threat and there is no well-defined pharmacological antiviral therapeutic choice so far, thereafter, the preventive measure has been the mainstay to fight back the current COVID-19 infection. On this account, this review explores the role of zinc and its properties as a strategy for defeating the COVID-19 pandemic. Even though zinc is a trace element, its significance as a micronutrient essential for maintaining the body's functionality such as vision, taste perception, cognition, cell reproduction, and growth cannot be undermined. ${ }^{80-82}$. Similarly, it is also considered a propeller of antiviral immunity, which increases both inherent and acquired immunity. ${ }^{105,106}$ This 
finding also accords to earlier observations that hold the view that increased uptake of zinc reflects positively on patients with several viral diseases such as torquetenovirus (TTV), common cold (rhinovirus). ${ }^{107-109}$ Conversely, it is interesting to note that individuals' increased susceptibility to viral infections has been significantly associated with low zinc levels. Certain facts corroborate that decreased zinc content levels are closely associated with risk factors like aging, immune deficiency, diabetes, obesity, and atherosclerosis that are relatively interconnected with COVID-19 cases. ${ }^{165-168}$ Consequently, zinc-deficient individuals are more inclined to severe viral infections like HIV and devastating outcomes in viral and bacterial co-infections. ${ }^{111,112}$ In the absence of any recognized the effective pharmacological therapeutic course of action, whereby, the uptake of Zinc as an antiviral agent and its immune-boosting feature is presumed to be a blueprint in surmounting the COVID-19 pandemic. ${ }^{105,106,121,122}$

Admittedly, only a few clinical studies and randomized control trials have been able to verify the immunity-boosting effects of zinc supplements; however, certain speculations have supported the fact that the modulation of a person's zinc status will most likely create a positive influence in the therapy of COVID-19. ${ }^{105,117}$ Evidence of this advantageous nature has been displayed through several modulation pathways such as fusion, replication, viral protein translation, and viral particle entry, especially respiratory system pathology. ${ }^{105,118,121,123,124}$ Additionally, its value proposition has not only been deemed fit in the treatment of COVID-19 but has specifically been linked to CQ efficiency. ${ }^{130,141,142}$ Thus, these reports show that even though this ideology has positive prospects, there is a need for further research into the adoption of zinc as a treatment measure. ${ }^{142}$ Considering the pros and cons of the consumption of zinc supplements, particularly in elderly persons or those with certain metabolic diseases: diabetes, obesity, or cardiovascular diseases, these views have supported the possibility of using zinc compounds as an adjunct therapy in COVID-19 treatment. ${ }^{105,125,144-146}$

Even though this compound's positive effect is widely accepted, critics have challenged its consumption rate, which could result in adverse effects if not treated with caution. These side effects have triggered epigastric pain, lethargy, vomiting, nausea, and fatigue. ${ }^{147,148}$ Generally, these observations have buttressed the notion that adequate zinc balance is crucial to protect an individual from microorganisms, including viral infections. Studies have claimed that an adequate level of zinc in individuals stimulates an increase in immune reactivity. The efficacy, tolerability, and safety of combining zinc with $\mathrm{CQ}$ remain a viable option in conquering COVID-19. ${ }^{11}$ Another considerable role of zinc is its activation and inactivation of numerous enzymes co-enzymes are crucial in cellular functions such as DNA synthesis, RNA transcription, and energy metabolism. ${ }^{153,154}$ However, prior studies have identified that any alteration to an individual's zinc contents increases their predisposition to several infectious and inflammatory conditions such as acquired immune deficiency syndrome, pneumonia, measles, malaria, tuberculosis, and others. ${ }^{84,155-157}$ Notably, it is often reported that a low level of zinc uptake may be a potential risk to an individuals' upper and lower respiratory tracts. ${ }^{112}$ Furthermore, earlier studies have shown that the prevalence of respiratory tract infections in children and adults has been linked to their Zinc uptake levels. ${ }^{112,158,159}$ In a review published by Singh and Das, ${ }^{169}$ consumption of zinc supplements have agreeably been critical in reducing both the incidental development of common cold and its duration in an already infected person. It is a widely held view that due to the antiviral property present in the consumption of Zinc, it is highly capable of reducing the intensity of COVID-19 infection as well as alleviating respiratory tract infections. ${ }^{105,173,178}$

There is a paucity of data on the efficacy of zinc therapy in the management of COVID-19 patients. However, many of the populace globally are ingesting zinc tablets, vitamin $\mathrm{C}$, and $\mathrm{B}$ vitamins based on antiviral and immune booster effects as preventive measures to combat COVID-19. For instance, a report from the United States-based retrospective analysis utilizing electronic medical records found that patients treated with hydroxychloroquine and azithromycin with the addition of zinc sulfate had a higher recovery rate. ${ }^{171}$ Surprisingly, additional uptake of zinc sulfate was identified to result in lower mortality rates, the need for hospice care, and less invasive ventilation requirements. A standard of care should accompany preventive measures by zinc supplements among COVID-19 patients as acute zinc toxicity described earlier. ${ }^{182-184}$ Thus, attention should be given to preventive and therapeutic doses, particularly for COVID-19 patients concerning age, gender, and comorbidity, to avoid further consequences. Finally, clinical studies on zinc considering its antiviral and immunityboosting potency must be further investigated to recognize its possible role in prophylactic and an adjuvant in treatment against SARS-CoV-2. 


\section{Primary Health Care in the Management of the Global Pandemic: Five to Ten Year Prospect}

The COVID-19 pandemic has struck a devastating blow to an already fragile global economy. Lockdowns and other restrictions needed to address the public health crisis, .... of adverse shocks that are causing deep recessions in many advanced economies and emerging market and developing economies (EMDEs). ${ }^{287}$

Epidemics are characterized by the Center for Disease Control and Prevention of the USA as an upsurge, sometimes abrupt, in the number of cases of a disease above what is normally predictable in that populace within this specific geographical region. The word outbreak conveys the same description of the epidemic; nonetheless, it is frequently castoff for a more restricted topographical zone. Pandemic mentions an epidemic that usually distresses many individuals and has blown through many republics or continents. ${ }^{288}$ The responsible causative microbes of pandemic and its' effective management vary extensively from country to country depending on its financial strength, health management capacities, and policies prerequisite for extenuation. Nevertheless, organizational diligence and response criteria are also identical. ${ }^{289,290}$ The COVID-19 pandemic resulted in 96,051,223 confirmed cases and over 2,050,543 deaths worldwide until January 19, 2021, 08:26 GMT. ${ }^{291}$ COVID19 has also flickered worries of an imminent pecuniary catastrophe and economic depression. ${ }^{292}$ The international economy will pull back around $5.2 \%$ in 2020 , according to the World Bank. ${ }^{293}$ The current expected recession (5.2\%) would be the most devastating since World War II. ${ }^{287}$ As public authorities need to impose strict movement control, lockdown, social distancing, self-isolation, travel restrictions, border shutdowns, and many more, ${ }^{294-296}$ to "flatten the COVID-19 curves". ${ }^{297,298}$ Although these restrictions save uncountable lives, as these measures minimize the labor force, it increases financial privation with the economic recession. $^{299-301}$

The coronavirus disease 2019 pandemic and its effects on health outcomes globally have further highlighted the importance of primary health care. ${ }^{302}$

It is a fact that primary health care (PHC) policy planning comprises a comprehensive approach to the overall improvement of people's health. ${ }^{303}$ Unfortunately, PHC remains deserted and poorly financed globally. ${ }^{304,305}$
Internationally, the healthcare budget is predominantly consumed in secondary and tertiary hospitals, and frequently PHC obtains a negligible share, ${ }^{306}$ after that, the health system when principally targeted towards medical and hospital-based services. The consequences are obvious - these health systems lose the enormous prospect of developing effective, efficient, and equitable ways based on PHC strategy to mitigate the principal causes of poor health. ${ }^{307,308}$ Currently, it is thought PHC based healthcare systems are essential for the counter to pandemics, as such of the COVID-19 pandemic, and for preserving important health services. ${ }^{309-311}$ As PHC is based on "social accountability, innovation, management, and population health,"312 the system ensures equity, especially marginalized communities with little attention regarding essential health services. ${ }^{312-314}$ Strengthening the PHC program effectively people's healthcare in terms of health outcome, maintaining equity, and healthcare access. Additionally, PHC successfully addresses all-important reasons for health miseries, thereby reducing morbidity and mortality, and is a costeffective approach for attaining universal health coverage (UHC). ${ }^{315-317}$

The countries (Taiwan, Hong Kong, South Korea, and Japan) heavily invested in PHC after SARS and MERS have managed much better than others. ${ }^{310,318-327}$ Taiwan took lessons from SARS on fighting back against the viral epidemic. $^{328,329}$ It has been reported that Taiwan successfully deferred and controlled community transmission of COVID-19 because the country experienced, learned, and utilized how to manage the viral epidemic of 2003. Moreover, the country positively developed awareness regarding the viral disease and its' atrocity, parallelly developed a strong public health system, supported by advanced tertiary healthcare industries, inter and intradepartmental teamwork, and innovative information technology. ${ }^{330}$ In this regard, Taiwan has established Community Healthcare Groups (CHCGs) since March 2003. These CHCGs act as the principal pillar of the PHC system in Taiwan as the front-line fighters for public health emergencies. ${ }^{319,331}$ As Taiwanese public authority recognized the threat of viral epidemic and timely invested heavily on the PHC program and the same paid back in combating COVID-19 pandemic. $^{318}$ Besides Taiwan, Hong Kong, and Singapore have also heavily invested in the PHC after the SARS epidemic. $^{332}$ These Asian nations equally controlled and manage COVID-19 much better than other countries of the globe. ${ }^{33}$ Japan established a universal health care system back in 1961. Regardless of their socioeconomic 
background, it has a consistent and, in reality, affordable fee schedule and no gatekeeping. ${ }^{334,335}$ Moreover, the Japanese health system covers the total population living in Japan and ensures access to health care services at a reasonable cost compared to similar high-income industrialist counties because it is regulated by public authority. ${ }^{336}$ Nonetheless, globally, Japan has a maximum number of geriatric communities, ${ }^{337}$ even then, COVID-19 caused mortality rate is much lower ( 9.24 deaths per million) than in many other high-income countries (ie, 529.92 in the USA, 609.92 in the UK, 110.61 in Germany). ${ }^{338}$ It is believed that as the health care system ensures equity, access to healthcare is operative for the entire population remains the key factor for the country's achievement in managing the COVID-19 pandemic. $^{338,339}$ Recently, the Japanese government renovated the PHC program with special attention to the elderly community. ${ }^{340}$ It is a well-known Japanese health program that achieves the highest life expectancy globally because of universal health coverage, which runs the PHC supported by advanced tertiary hospital service. ${ }^{341}$ Thereafter, the COVID-19 pandemic once again divides our planet into countries that have robust healthcare based on PHC concept to ensure healthcare access for the entire population irrespective of socioeconomic status or like those countries have policy those who can afford healthcare only access to healthcare and rest those who cannot pay for will be enforced into life-threatening poverty. ${ }^{298,342}$ Moreover, the COVID-19 pandemic raises the issue of collaboration and cooperation between all sectors of communities involved in healthcare both nationally and internationally. ${ }^{298}$ Collaboration and cooperation are the basic notion of PHC. ${ }^{343-346}$ Additionally, both national and international policy must remember that "until every country is safe, no country will be safe." 298

This research expects that in the next five to ten years' time scientific arena and all healthcare stakeholders will have better collaboration and coordination between public and non-governmental organizations of national and international level to promote improved healthcare for all. ${ }^{347-349}$ Researchers expect one-decade time hopefully, all countries, especially lower-and-middle income countries, will be able to strengthen the healthcare system based on the PHC concept to ensure health-related equity. ${ }^{307-350-355}$ Subsequently, our planet may have universal health coverage based on the PHC concept to fight back any future viral pandemic like COVID-19 and improve access and equity healthcare.

\section{Article Highlights}

- Zinc is an essential trace element that vitalizes human growth and development and boosts antiviral immunity. The antiviral effects of zinc have been documented in several viral diseases. ${ }^{74-100}$

- This review is intended to highlight Zinc's role in boosting immunity and narrate Zinc's antiviral activity, efficacy, and safety in combating COVID-19. ${ }^{105-126}$

- Zinc-deficient individuals are prone to develop severe viral infections and viral-bacterial co-infections. ${ }^{11,112,117}$

- Clinical trials showed zinc supplements to improve oxygen saturation in respiratory system pathology. ${ }^{11,115}$

- Zinc ionophore pyrithione was reported to inhibit SARS-coronavirus RNA polymerase activity. ${ }^{130,140}$

- Some preliminary research identified Zn ionophore stimulates zinc's efficiency in its antiviral ability against COVID-19. ${ }^{142,190,191}$

\section{Acknowledgment}

The authors are grateful to Prof. Mohammed S. Razzaque, MBBS, Ph.D. of Lake Erie College of Osteopathic Medicine (Pennsylvania, USA), for providing useful suggestions.

\section{Author Contributions}

All authors made a significant contribution to the work reported, whether that is in the conception, study design, execution, acquisition of data, analysis, and interpretation, or in all these areas; took part in drafting, revising, or critically reviewing the article; gave final approval of the version to be published; have agreed on the journal to which the essay has been submitted; and agree to be accountable for all aspects of the work.

\section{Disclosure}

The authors declare that they do not have any financial involvement or affiliations with any organization, association, or entity directly or indirectly with the subject matter or materials presented in this article. This also includes honoraria, expert testimony, employment, ownership of stocks or options, patents or grants received or pending, or royalties.

\section{References}

1. She J, Jiang J, Ye L, Hu L, Bai C, Song Y. 2019 novel coronavirus of pneumonia in Wuhan, China: emerging attack and management strategies. Clin Transl Med. 2020;9(1):19. doi:10.1186/s40169-020-002 $71-\mathrm{z}$ 
2. Liu YC, Kuo RL, Shih SR. COVID-19: the first documented coronavirus pandemic in history. Biomed J. 2020;43(4):328333. doi:10.1016/j.bj.2020.04.007

3. World Health Organization. COVID-19 Public Health Emergency of International Concern (PHEIC) Global research and innovation forum; 2020. Available from: https://www.who.int/publications/ $\mathrm{m} /$ item/covid-19-public-health-emergency-of-international-con cern-(pheic)-global-research-and-innovation-forum. Accessed October 30, 2020.

4. Wu F, Zhao S, Yu B, et al. A new coronavirus associated with human respiratory disease in China. Nature. 2020;579 (7798):265-269. doi:10.1038/s41586-020-2008-3

5. Peeri NC, Shrestha N, Rahman MS, et al. The SARS, MERS and novel coronavirus (COVID-19) epidemics, the newest and biggest global health threats: what lessons have we learned? Int $J$ Epidemiol. 2020;49(3):717-726. doi:10.1093/ije/dyaa033

6. World Health Organization. WHO director-general's opening remarks at the mission briefing on COVID-19-12 March 2020; 2020. Available from: https://www.who.int/dg/speeches/ detail/who-director-general-s-opening-remarks-at-the-missionbriefing-on-covid-19-12-march-2020. Accessed October 30, 2020.

7. Hamid S, Mir MY, Rohela GK. Novel coronavirus disease (COVID-19): a pandemic (epidemiology, pathogenesis, and potential therapeutics). New Microbes New Infect. 2020;35:100679. doi:10.1016/j.nmni.2020.100679

8. Coronaviridae Study Group of the International Committee on Taxonomy of Viruses. The species Severe acute respiratory syndrome-related coronavirus: classifying 2019-nCoV and naming it SARS-CoV-2. Nat Microbiol. 2020;5(4):536-544. doi:10.1038/ s41564-020-0695-z.

9. Wu Y, Ho W, Huang Y, et al. SARS-CoV-2 is an appropriate name for the new coronavirus. Lancet. 2020;395(10228):949950. doi:10.1016/S0140-6736(20)30557-2

10. World Health Organization. WHO coronavirus disease (COVID19) dashboard. Data last updated: 2020/12/1, 4:28 pm CET Overview Data Table; 2020. Available from: https://covid19. who.int/?gclid=CjwKCAjw8-78BRA0EiwAFUw8LAR8elp5pjv_ gRFZLrIsKzI5 yfkTmkVAEC0La $7 \mathrm{MjyOzHWfdL2E-}$ gKRoC6kIQAvD_BwE. Accessed January 19, 2021.

11. Johnson NP, Mueller J. Updating the accounts: global mortality of the 1918-1920 "Spanish" influenza pandemic. Bull Hist Med. 2002;76(1):105-115. doi:10.1353/bhm.2002.0022

12. Erkoreka A. The Spanish influenza pandemic in occidental Europe (1918-1920) and victim age. Influenza Other Respir Viruses. 2010;4(2):81-89. doi:10.1111/j.1750-2659. 2009.00125.x

13. Ansart S, Pelat C, Boelle PY, Carrat F, Flahault A, Valleron AJ. Mortality burden of the 1918-1919 influenza pandemic in Europe. Influenza Other Respir Viruses. 2009;3(3):99-106. doi:10.1111/j.1750-2659.2009.00080.x

14. Kain T, Fowler R. Preparing intensive care for the next pandemic influenza. Crit Care. 2019;23(1):337. doi:10.1186/s13054-0192616-1

15. Sutton TC. The pandemic threat of emerging H5 and H7 Avian influenza viruses. Viruses. 2018;10(9):461. doi:10.3390/ v10090461

16. Simonsen L, Clarke MJ, Schonberger LB, Arden NH, Cox NJ, Fukuda K. Pandemic versus epidemic influenza mortality: a pattern of changing age distribution. J Infect Dis. 1998;178(1):5360. doi:10.1086/515616

17. Turbelin C, Souty C, Pelat C, et al. Age distribution of influenzalike illness cases during post-pandemic $\mathrm{A}(\mathrm{H} 3 \mathrm{~N} 2)$ : comparison with the twelve previous seasons, in France. PLoS One. 2013;8 (6):e65919. doi:10.1371/journal.pone.0065919
18. Buchholz U, Buda S, Reuß A, Haas W, Uphoff H. Todesfälle durch Influenzapandemien in Deutschland 1918 bis 2009. Schätzwerte auf Basis der Literatur und ergänzende eigene Berechnungen [Influenza pandemic deaths in Germany from 1918 to 2009. Estimates based on literature and own calculations]. Bundesgesundheitsblatt Gesundheitsforschung Gesundheitsschutz. 2016;59(4):523-536. German. PMID: 26984565.. doi:10.1007/ s00103-016-2324-9.

19. Viboud C, Simonsen L, Fuentes R, Flores J, Miller MA, Chowell G. Global mortality impact of the 1957-1959 influenza pandemic. J Infect Dis. 2016;213(5):738-745. doi:10.1093/ infdis/jiv534

20. Lemaitre M, Carrat F, Rey G, Miller M, Simonsen L, Viboud C. Mortality burden of the 2009 A/H1N1 influenza pandemic in France: comparison to seasonal influenza and the A/H3N2 pandemic. PLoS One. 2012;7(9):e45051. doi:10.1371/journal.pone. 0045051

21. Dawood FS, Iuliano AD, Reed C, et al. Estimated global mortality associated with the first 12 months of 2009 pandemic influenza A H1N1 virus circulation: a modeling study. Lancet Infect Dis. 2012;12(9):687-695. doi:10.1016/S1473-3099(12)70121-4

22. Morens DM, Taubenberger JK, Harvey HA, Memoli MJ. The 1918 influenza pandemic: lessons for 2009 and the future. Crit Care Med. 2010;38(4 Suppl):e10-e20. doi:10.1097/CCM.0b0 $13 \mathrm{e} 3181 \mathrm{ceb} 25 \mathrm{~b}$

23. Andreasen V, Viboud C, Simonsen L. Epidemiologic characterization of the 1918 influenza pandemic summer wave in Copenhagen: implications for pandemic control strategies. $J$ Infect Dis. 2008;197(2):270-278. doi:10.1086/524065

24. Taubenberger JK. The origin and virulence of the 1918 "Spanish" influenza virus. Proc Am Philos Soc. 2006;150(1):86-112.

25. Patterson KD, Pyle GF. The geography and mortality of the 1918 influenza pandemic. Bull Hist Med. 1991;65(1):4-21.

26. Taubenberger JK. The virulence of the 1918 pandemic influenza virus: unraveling the enigma. Arch Virol Suppl. 2005;19:101-115. doi:10.1007/3-211-29981-5_9

27. Burnet FM, Clark E. Influenza: A Survey of the Last 50 Years in the Light of Modern Work on the Virus of Epidemic Influenza. Melbourne: Macmillan and Company, Limited; 1942.

28. Frost WH. Statistics of influenza morbidity: with special reference to certain factors in case incidence and case fatality. Public Health Rep. 1920;35(11):584-597. doi:10.2307/4575511

29. Franco-Paredes C, Hernandez-Ramos I, Del Rio C, Alexander KT, Tapia-Conyer R, Santos-Preciado JI. H1N1 influenza pandemics: comparing the events of 2009 in Mexico with those of 1976 and 1918-1919. Arch Med Res. 2009;40(8):669-672. doi:10.1016/j.arcmed.2009.10.004

30. Marks G, Beatty WK. Epidemics. 1st ed. New York: Charles Scribner's Sons; 1976.

31. Wallace R, Kohatsu N. Maxcy-Rosenau-Last Public Health \& Preventive Medicine. 15th ed. New York: McGraw-Hill Medical; 2008.

32. Noymer A, Garenne M. The 1918 influenza epidemic's effects on sex differentials in mortality in the United States. Popul Dev Rev. 2000;26(3):565-581. doi:10.1111/j.1728-4457.2000.00565.x

33. Billings $M$ The influenza pandemic of 1918. First Published 1997; 2005. Available from: https://virus.stanford.edu/uda/\#: : text $=$ The $\% 20$ death $\% 20$ rate $\% 20$ for $\% 2015$,street $\% 20$ and $\% 20$ died \%20rapid\%20deaths. Accessed October 31, 2020.

34. Crosby A. America's Forgotten Pandemic. Cambridge, UK: Cambridge University Press; 1989.

35. Reid AH, Fanning TG, Hultin JV, Taubenberger JK. Origin and evolution of the 1918 "Spanish" influenza virus hemagglutinin gene. Proc Natl Acad Sci USA. 1999;96(4):1651-1656. doi:10. 1073/pnas.96.4.1651 
36. Craig R Why Did the 1918 Flu Kill So Many Otherwise Healthy Young Adults? Uncovering a World War, I veteran's story provided a genealogist and pharmacologist with some clues. The Conservation. The Next Pandemic. Johns Hopkins Blomberg School of Public Health and Smithsonian, National Museum of Natural History; 2017. Available from: https://www.smithsonian mag.com/history/why-did-1918-flu-kill-so-many-otherwisehealthy-young-adults-180967178/. Accessed November 3, 2020.

37. Morens DM, Taubenberger JK, Fauci AS. Predominant role of bacterial pneumonia as a cause of death in pandemic influenza: implications for pandemic influenza preparedness. J Infect Dis. 2008;198(7):962-970. doi:10.1086/591708

38. Taubenberger JK, Morens DM. The pathology of influenza virus infections. Annu Rev Pathol. 2008;3:499-522. doi:10.1146/ annurev.pathmechdis.3.121806.154316

39. Hsieh YC, Wu TZ, Liu DP, et al. Influenza pandemics: past, present, and future. J Formos Med Assoc. 2006;105(1):1-6. doi:10.1016/S0929-6646(09)60102-9

40. Metersky ML, Masterton RG, Lode H, File TM Jr, Babinchak T. Epidemiology, microbiology, and treatment considerations for bacterial pneumonia complicating influenza. Int $J$ Infect Dis. 2012;16(5):e321-31. doi:10.1016/j.ijid.2012.01.003

41. LeCount ER. The pathologic anatomy of influenzal bronchopneumonia. JAMA. 1919;72:650-652. doi:10.1001/jama.1919.02610 090034009

42. Winternitz MC, Wason IM, McNamara FP. The Pathology of Influenza. New Haven: Yale University Press; 1920.

43. Wolbach SB. Comments on the pathology and bacteriology of fatal influenza cases, as observed at Camp Devens, Mass. Johns Hopkins Hosp Bull. 1919;30:104.

44. Mauad T, Hajjar LA, Callegari GD, et al. Lung pathology in fatal novel human influenza A (H1N1) infection. Am J Respir Crit Care Med. 2010;181(1):72-79. doi:10.1164/rccm.200909-1420OC

45. Gilbert CR, Vipul K, Baram M. Novel H1N1 influenza A viral infection complicated by alveolar hemorrhage. Respir Care. 2010;55(5):623-625.

46. Taubenberger JK, Morens DM. Influenza: the once and future pandemic. Public Health Rep. 2010;125(Suppl 3):16-26. doi:10.1177/00333549101250S305

47. Taubenberger JK, Reid AH, Janczewski TA, Fanning TG. Integrating historical, clinical, and molecular genetic data in order to explain the origin and virulence of the 1918 Spanish influenza virus. Philos Trans R Soc Lond B Biol Sci. 2001;356 (1416):1829-1839. doi:10.1098/rstb.2001.1020

48. Rivera-Perez JI, Santiago-Rodriguez TM, Toranzos GA. Paleomicrobiology: a snapshot of ancient microbes and approaches to forensic microbiology. Microbiol Spectr. 2016;4 (4). doi:10.1128/microbiolspec.EMF-0006-2015

49. Raoult D, Aboudharam G, Crubézy E, Larrouy G, Ludes B, Drancourt M. Molecular identification by "suicide PCR" of Yersinia pestis as the agent of medieval black death. Proc Natl Acad Sci USA. 2000;97 (23):12800-12803. doi:10.1073/pnas.220225197

50. Rafi A, Spigelman M, Stanford J, Lemma E, Donoghue H, Zias J. Mycobacterium leprae DNA from ancient bone detected by PCR Lancet. 1994;343(8909):1360-1361. doi:10.1016/S0140-6736(94) 92494-5

51. Kolman CJ, Centurion-Lara A, Lukehart SA, Owsley DW, Tuross $\mathrm{N}$. Identification of Treponema pallidum subspecies pallidum in a 200-year-old skeletal specimen. J Infect Dis. 1999;180(6):20602063. doi: $10.1086 / 315151$

52. Drancourt M, Aboudharam G, Signoli M, Dutour O, Raoult D. Detection of 400-year-old Yersinia pestis DNA in human dental pulp: an approach to the diagnosis of ancient septicemia. Proc Natl Acad Sci USA. 1998;95(21):12637-12640. doi:10.1073/ pnas.95.21.12637
53. Taubenberger JK, Reid AH, Krafft AE, Bijwaard KE, Fanning TG. Initial genetic characterization of the 1918 "Spanish" influenza virus. Science. 1997;275(5307):1793-1796. doi:10.1126/ science.275.5307.1793

54. Lina B. History of influenza pandemics. Paleomicrobiology. 2008;199-211. doi:10.1007/978-3-540-75855-6_12

55. Basler CF, Reid AH, Dybing JK, et al. Sequence of the 1918 pandemic influenza virus nonstructural gene (NS) segment and characterization of recombinant viruses bearing the 1918 NS genes. Proc Natl Acad Sci USA. 2001;98(5):2746-2751. doi:10.1073/pnas.031575198

56. Xiao YL, Kash JC, Beres SB, Sheng ZM, Musser JM, Taubenberger JK. High-throughput RNA sequencing of a formalin-fixed, paraffin-embedded autopsy lung tissue sample from the 1918 influenza pandemic. J Pathol. 2013;229(4):535-545. doi:10.1002/path.4145

57. Reid AH, Fanning TG, Janczewski TA, Taubenberger JK. Characterization of the 1918 "Spanish" influenza virus neuraminidase gene. Proc Natl Acad Sci USA. 2000;97(12):6785-6790. doi:10.1073/pnas.100140097

58. Denison AM, Blau DM, Jost HA, et al. Diagnosis of influenza from respiratory autopsy tissues: detection of virus by real-time reverse transcription-PCR in 222 cases. $J$ Mol Diagn. 2011;13 (2):123-128. doi:10.1016/j.jmoldx.2010.09.004

59. Impellizzeri FM, Bizzini M. Systematic review and meta-analysis: a primer. Int J Sports Phys Ther. 2012;7(5):493-503.

60. Ahn E, Kang H. Introduction to systematic review and metaanalysis. Korean J Anesthesiol. 2018;71(2):103-112. doi:10.40 97/kjae.2018.71.2.103

61. Gasparyan AY, Ayvazyan L, Blackmore H, Kitas GD. Writing a narrative biomedical review: considerations for authors, peer reviewers, and editors. Rheumatol Int. 2011;31(11):1409-1417. doi:10.1007/s00296-011-1999-3

62. Baethge C, Goldbeck-Wood S, Mertens S. SANRA-a scale for the quality assessment of narrative review articles. Res Integr Peer Rev. 2019;4:5. doi:10.1186/s41073-019-0064-8

63. Mulrow CD. The medical review article: state of the science. Ann Intern Med. 1987;106(3):485-488. doi:10.7326/0003-4819-106-3485

64. McAlister FA, Clark HD, van Walraven C, et al. The medical review article revisited: has the science improved? Ann Intern Med. 1999;131(12):947-951. doi:10.7326/0003-4819-131-12-19 9912210-00007

65. Roohani N, Hurrell R, Kelishadi R, Schulin R. Zinc and its importance for human health: an integrative review. $J$ Res Med Sci. 2013;18(2):144-157.

66. Prasad AS. Clinical, immunological, anti-inflammatory, and antioxidant roles of zinc. Exp Gerontol. 2008;43(5):370-377. doi:10. 1016/j.exger.2007.10.013

67. Prasad AS, Miale A Jr, Farid Z, Sandstead HH, Schulert AR. Zinc metabolism in patients with the syndrome of iron deficiency anemia, hepatosplenomegaly, dwarfism, and hypogonadism. $J$ Lab Clin Med. 1963;61:537-549.

68. Raulin J. [Chemical studies on vegetation.]. Ann Sci Nat. 1869;11:93-99. French.

69. Sommer AL, Lipman CB. Evidence on the indispensable nature of zinc and boron for higher green plants. Plant Physiol. 1926;1 (3):231-249. doi:10.1104/pp.1.3.231

70. Todd WR, Elvehjem CA, Hart EB. Zinc in the nutrition of the rat. Am J Physiol. 1934;107:146-156. doi:10.1152/ajplegacy.1933.10 7.1.146

71. Blamberg DL, Blackwood UB, Supplee WC, Combs GF. Effect of zinc deficiency in hens on hatchability and embryonic development. Proc Soc Exp Biol Med. 1960;104:217-220. doi:10.3181/ 00379727-104-25784 
72. O'dell BL, Newberne PM, Savage JE. Significance of dietary zinc for the growing chicken. $J$ Nutr. 1958;65(4):503-518. doi:10.10 93/jn/65.4.503

73. Tucker HF, Salmon WD. Parakeratosis or zinc deficiency disease in the pig. Proc Soc Exp Biol Med. 1955;88(4):613-616. doi:10. 3181/00379727-88-21670

74. Prasad AS, Sandstead HH, Schulert AR, El-Rooby AS. Urinary excretion of zinc in patients with the syndrome of anemia, hepatosplenomegaly, dwarfism, and hypogonadism. J Lab Clin Med. $1963 ; 62: 591-599$.

75. Moynahan EJ. Letter: acrodermatitis enteropathica: a lethal, inherited human zinc-deficiency disorder. Lancet. 1974;2 (7877):399-400. doi:10.1016/s0140-6736(74)91772-3

76. Barnes PM, Moynahan EJ. Zinc deficiency in acrodermatitis enteropathica: multiple dietary intolerances treated with synthetic diet. Proc R Soc Med. 1973;66(4):327-329.

77. Hambidge KM, Walravens PA. Disorders of mineral metabolism. Clin Gastroenterol. 1982;11(1):87-117.

78. Sandstead HH. Zinc deficiency. A public health problem? Am J Dis Child. 1991;145(8):853-859. doi:10.1001/archpedi.1991.02 160080029016

79. Black MM. Zinc deficiency and child development. Am J Clin Nutr. 1998;68(2Suppl):464S-469S. doi:10.1093/ajcn/ 68.2.464S

80. Brown KH, Peerson JM, Rivera J, Allen LH. Effect of supplemental zinc on the growth and serum zinc concentrations of prepubertal children: a meta-analysis of randomized controlled trials. Am J Clin Nutr. 2002;75(6):1062-1071. doi:10.1093/ajcn/ 75.6.1062

81. Sharma A, Patni B, Shankhdhar D, Shankhdhar SC. Zinc - an indispensable micronutrient. Physiol Mol Biol Plants. 2013;19 (1):11-20. doi:10.1007/s12298-012-0139-1

82. Bhattacharya PT, Misra SR, Hussain M. Nutritional aspects of essential trace elements in oral health and disease: an extensive review. Scientifica (Cairo). 2016;2016:5464373. doi:10.1155/ 2016/5464373

83. Hojyo S, Fukada T. Roles of zinc signaling in the immune system. J Immunol Res. 2016;2016:6762343. doi:10.1155/2016/6762343

84. Gammoh NZ, Rink L. Zinc in infection and inflammation. Nutrients. 2017;9(6):624. doi:10.3390/nu9060624

85. Jarosz M, Olbert M, Wyszogrodzka G, Młyniec K, Librowski T. Antioxidant and anti-inflammatory effects of Zinc. Zinc-dependent NF-кB signaling. Inflammopharmacology. 2017;25(1):1124. doi:10.1007/s10787-017-0309-4

86. McCall KA, Huang C, Fierke CA. Function and mechanism of zinc metalloenzymes. J Nutr. 2000;130(5SSuppl):1437S-46S. doi:10.1093/jn/130.5.1437S

87. Robinson PK. Enzymes: principles and biotechnological applications. Essays Biochem. 2015;59:1-41. doi:10.1042/bse0590001

88. Alker W, Haase H. Zinc, and sepsis. Nutrients. 2018;10(8):976. doi:10.3390/nu10080976

89. Cousins RJ, Aydemir TB, Lichten LA. Plenary lecture 2: transcription factors, regulatory elements, and nutrient-gene communication. Proc Nutr Soc. 2010;69(1):91-94. doi:10.1017/ S0029665109991790

90. Liu T, Zhang L, Joo D, Sun SC. NF- $\kappa$ B signaling in inflammation. Signal Transduct Target Ther. 2017;2:17023. doi:10.1038/ sigtrans.2017.23

91. DeDiego ML, Nieto-Torres JL, Regla-Nava JA, et al. Inhibition

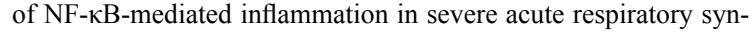
drome coronavirus-infected mice increases survival. $J$ Virol. 2014;88(2):913-924. doi:10.1128/JVI.02576-13

92. Abraham E, Singer M. Mechanisms of sepsis-induced organ dysfunction. Crit Care Med. 2007;35(10):2408-2416. doi:10.1097/01.ccm.0000282072.56245.91
93. Li X, Su J, Cui X, Li Y, Barochia A, Eichacker PQ. Can we predict the effects of NF-kappaB inhibition in sepsis? Studies with parthenolide and ethyl pyruvate. Expert Opin Investig Drugs. 2009;18(8):1047-1060. doi:10.1517/135437809 03018880

94. Arnalich F, Garcia-Palomero E, López J, et al. Predictive value of nuclear factor kappaB activity and plasma cytokine levels in patients with sepsis. Infect Immun. 2000;68(4):1942-1945. doi:10.1128/iai.68.4.1942-1945.2000

95. Younus H. Therapeutic potentials of superoxide dismutase. Int $J$ Health Sci (Qassim). 2018;12(3):88-93.

96. Marreiro DD, Cruz KJ, Morais JB, Beserra JB, Severo JS, de Oliveira AR. Zinc and oxidative stress: current mechanisms. Antioxidants (Basel). 2017;6(2):24. doi:10.3390/antiox6020024

97. Cruz KJ, de Oliveira AR, Marreiro Ddo N. Antioxidant role of zinc in diabetes mellitus. World J Diabetes. 2015;6(2):333-337. doi:10.4239/wjd.v6.i2.333

98. Oteiza PI, Clegg MS, Zago MP, Keen CL. Zinc deficiency induces oxidative stress and AP-1 activation in 3T3 cells. Free Radic Biol Med. 2000;28(7):1091-1099. doi:10.1016/s0891-5849 (00)00200-8

99. Oteiza PI. Zinc and the modulation of redox homeostasis. Free Radic Biol Med. 2012;53(9):1748-1759. doi:10.1016/j. freeradbiomed.2012.08.568

100. Lee SR. Critical role of zinc as either an antioxidant or a prooxidant in cellular systems. Oxid Med Cell Longev. 2018;2018:9156285. doi:10.1155/2018/9156285

101. Maret W. Zinc and sulfur: a critical biological partnership. Biochemistry. 2004;43(12):3301-3309. doi:10.1021/bi036340p

102. Prasad AS. Discovery of human zinc deficiency: its impact on human health and disease. Adv Nutr. 2013;4(2):176-190. doi:10.3945/an.112.003210

103. Prasad AS. Impact of the discovery of human zinc deficiency on health. J Trace Elem Med Biol. 2014;28(4):357-363. doi:10.1016/ j.jtemb.2014.09.002

104. Prasad AS. Discovery of human zinc deficiency: 50 years later. $J$ Trace Elem Med Biol. 2012;26(2-3):66-69. doi:10.1016/j. jtemb.2012.04.004

105. Read SA, Obeid S, Ahlenstiel C, Ahlenstiel G. The role of zinc in antiviral immunity. Adv Nutr. 2019;10(4):696-710. doi:10.1093/ advances/nmz013

106. Jayawardena R, Sooriyaarachchi P, Chourdakis M, Jeewandara C, Ranasinghe P. Enhancing immunity in viral infections, with special emphasis on COVID-19: a review. Diabetes Metab Syndr. 2020;14(4):367-382. doi:10.1016/j.dsx.2020.04.015

107. Iovino L, Mazziotta F, Carulli G, et al. High-dose zinc oral supplementation after stem cell transplantation causes an increase of TRECs and CD4+ naïve lymphocytes and prevents TTV reactivation. Leuk Res. 2018;70:20-24. doi:10.1016/j.leukres.2018.04.016

108. Albers R, Bourdet-Sicard R, Braun D, et al. Monitoring immune modulation by nutrition in the general population: identifying and substantiating effects on human health. Br J Nutr. 2013;110(Suppl 2):S1-S30. doi:10.1017/S0007114513001505

109. Rao G, Rowland K. PURLs: zinc for the common cold-not if, but when. J Fam Pract. 2011;60(11):669-671.

110. Basnet S, Mathisen M, Strand TA. Oral zinc and common childhood infections-An update. $J$ Trace Elem Med Biol. 2015;31:163-166. doi:10.1016/j.jtemb.2014.05.006

111. Derwand R, Scholz M. Does zinc supplementation enhance the clinical efficacy of chloroquine/hydroxychloroquine to win today's battle against COVID-19? Med Hypotheses. 2020;142:109815. doi:10.1016/j.mehy.2020.109815

112. Skalny AV, Rink L, Ajsuvakova OP, et al. Zinc and respiratory tract infections: perspectives for COVID-19 (Review). Int $\mathrm{J} \mathrm{Mol}$ Med. 2020;46(1):17-26. doi:10.3892/ijmm.2020.4575 
113. Livingston E, Desai A, Berkwits M. Sourcing personal protective equipment during the COVID-19 pandemic. JAMA. 2020;323 (19):1912-1914. doi:10.1001/jama.2020.5317

114. Yang F, Zhang Y, Tariq A, et al. Food as medicine: a possible preventive measure against coronavirus disease (COVID-19). Phytother Res. 2020;34(12):3124-3136. doi:10.1002/ptr.6770

115. Rerksuppaphol S, Rerksuppaphol L. A randomized controlled trial of zinc supplementation in the treatment of acute respiratory tract infection in Thai children. Pediatr Rep. 2019;11(2):7954. doi:10.4081/pr.2019.7954

116. Linko R, Karlsson S, Pettilä V, et al. Serum zinc in critically ill adult patients with acute respiratory failure. Acta Anaesthesiol Scand. 2011;55(5):615-621. doi:10.1111/j.1399-6576.2011.02425.x

117. Hemilä H, Haukka J, Alho M, Vahtera J, Kivimäki M. Zinc acetate lozenges for the treatment of the common cold: a randomized controlled trial. BMJ Open. 2020;10(1):e031662. doi:10.1136/bmjopen-2019-031662

118. Mayor-Ibarguren A, Busca-Arenzana C, Robles-Marhuenda Á. A hypothesis for the possible role of zinc in the immunological pathways related to COVID-19 infection. Front Immunol. 2020;11:1736. doi:10.3389/fimmu.2020.01736

119. Lyu J, Miao T, Dong J, Cao R, Li Y, Chen Q. Reflection on lower rates of COVID-19 in children: does childhood immunizations offer unexpected protection? Med Hypotheses. 2020;143:109842. doi:10.1016/j.mehy.2020.109842

120. Lee PI, Hu YL, Chen PY, Huang YC, Hsueh PR. Are children less susceptible to COVID-19? J Microbiol Immunol Infect. 2020;53(3):371-372. doi:10.1016/j.jmii.2020.02.011

121. Wessels I, Rolles B, Rink L. The potential impact of zinc supplementation on COVID-19 pathogenesis. Front Immunol. 2020;11:1712. doi:10.3389/fimmu.2020.01712

122. Hemilä H, Fitzgerald JT, Petrus EJ, Prasad A. Zinc acetate lozenges may improve the recovery rate of common cold patients: an individual patient data meta-analysis. Open Forum Infect Dis. 2017;4(2):ofx059. doi:10.1093/ofid/ofx059

123. Razzaque MS. COVID-19 pandemic: can maintaining optimal zinc balance enhance host resistance? Tohoku J Exp Med. 2020;251(3):175-181. doi:10.1620/tjem.251.175

124. Heller RA, Sun Q, Hackler J, et al. Prediction of survival odds in COVID-19 by zinc, age and selenoprotein $\mathrm{P}$ as composite biomarker. Redox Biol. 2020;38:101764. doi:10.1016/j.redox.2020. 101764

125. Zhang L, Liu Y. Potential interventions for novel coronavirus in China: a systematic review. J Med Virol. 2020;92(5):479-490. doi:10.1002/jmv.25707

126. Kumar A, Kubota Y, Chernov M, Kasuya H. Potential role of zinc supplementation in prophylaxis and treatment of COVID19. Med Hypotheses. 2020;144:109848. doi:10.1016/j. mehy.2020.109848

127. Darma A, Ranuh RG, Merbawani W, et al. Zinc supplementation effect on the bronchial cilia length, the number of cilia, and the number of intact bronchial cell in zinc deficiency rats. Indones Biomed J. 2020;12(1):78-84. doi:10.18585/inabj.v12i1.998

128. Truong-Tran AQ, Carter J, Ruffin R, Zalewski PD. New insights into the role of zinc in the respiratory epithelium. Immunol Cell Biol. 2001;79(2):170-177. doi:10.1046/j.1440-1711.2001.00986.x

129. Roscioli E, Jersmann HP, Lester S, et al. Zinc deficiency as a codeterminant for airway epithelial barrier dysfunction in an ex vivo model of COPD. Int $J$ Chron Obstruct Pulmon Dis. 2017;12:3503-3510. doi:10.2147/COPD.S149589

130. Te Velthuis AJ, van den Worm SH, Sims AC, Baric RS, Snijder EJ, van Hemert MJ. $\mathrm{Zn}^{2+}$ inhibits coronavirus and arterivirus RNA polymerase activity in vitro, and zinc ionophores block the replication of these viruses in cell culture. PLoS Pathog. 2010;6(11):e1001176. doi:10.1371/journal.ppat.1001176
131. Rosenkranz E, Metz CH, Maywald M, et al. Zinc supplementation induces regulatory $\mathrm{T}$ cells by inhibition of Sirt-1 deacetylase in mixed lymphocyte cultures. Mol Nutr Food Res. 2016;60 (3):661-671. doi:10.1002/mnfr.201500524

132. Berg K, Bolt G, Andersen H, Owen TC. Zinc potentiates the antiviral action of human IFN-alpha tenfold. $J$ Interferon Cytokine Res. 2001;21(7):471-474. doi:10.1089/1079990015 2434330

133. Lin FC, Young HA. Interferons: success in anti-viral immunotherapy. Cytokine Growth Factor Rev. 2014;25(4):369-376. doi:10. 1016/j.cytogfr.2014.07.015

134. Ntyonga-Pono MP. COVID-19 infection and oxidative stress: an under-explored approach for prevention and treatment? Pan Afr Med J. 2020;35(Supp12):12. doi:10.11604/ pamj.2020.35.2.22877

135. Lang CJ, Hansen M, Roscioli E, et al. Dietary zinc mediates inflammation and protects against wasting and metabolic derangement caused by sustained cigarette smoke exposure in mice. Biometals. 2011;24(1):23-39. doi:10.1007/s10534-0109370-9

136. Wessels I, Haase H, Engelhardt G, Rink L, Uciechowski P. Zinc deficiency induces production of the proinflammatory cytokines IL-1 $\beta$ and TNF $\alpha$ in promyeloid cells via epigenetic and redoxdependent mechanisms. J Nutr Biochem. 2013;24(1):289-297. doi:10.1016/j.jnutbio.2012.06.007

137. Jeon KI, Jeong JY, Jue DM. Thiol-reactive metal compounds inhibit NF-kappa B activation by blocking I kappa B kinase. $J$ Immunol. 2000;164(11):5981-5989. doi:10.4049/jimmunol.164. 11.5981

138. Prasad AS, Bao B, Beck FW, Sarkar FH. Zinc-suppressed inflammatory cytokines by induction of A20-mediated inhibition of

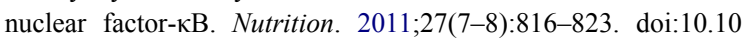
16/j.nut.2010.08.010

139. Wellinghausen N, Martin M, Rink L. Zinc inhibits interleukin-1dependent T cell stimulation. Eur J Immunol. 1997;27(10):25292535. doi:10.1002/eji.1830271010

140. Shittu MO, Afolami OI. Improving the efficacy of chloroquine and hydroxychloroquine against SARS-CoV-2 may require Zinc additives - A better synergy for future COVID-19 clinical trials. Infez Med. 2020;28(2):192-197. doi:10.3389/fimmu.2019.02347

141. Wang M, Cao R, Zhang L, et al. Remdesivir and chloroquine effectively inhibit the recently emerged novel coronavirus (2019nCoV) in vitro. Cell Res. 2020;30(3):269-271. doi:10.1038/ s41422-020-0282-0

142. Xue J, Moyer A, Peng B, Wu J, Hannafon BN, Ding WQ. Chloroquine is a zinc ionophore. PLoS One. 2014;9(10): e109180. doi:10.1371/journal.pone.0109180

143. Guastalegname M, Vallone A. Could chloroquine/hydroxychloroquine be harmful in coronavirus disease 2019 (COVID-19) treatment? Clin Infect Dis. 2020;71(15):888-889. doi:10.1093/ $\mathrm{cid} / \mathrm{ciaa} 321$

144. Wessels I, Maywald M, Rink L. Zinc as a gatekeeper of immune function. Nutrients. 2017;9(12):1286. doi:10.3390/nu9121286

145. Olechnowicz J, Tinkov A, Skalny A, Suliburska J. Zinc status is associated with inflammation, oxidative stress, lipid, and glucose metabolism. J Physiol Sci. 2018;68(1):19-31. doi:10.1007/ s12576-017-0571-7

146. Haase H, Rink L. The immune system and the impact of zinc during aging. Immun Ageing. 2009;6:9. doi:10.1186/1742-49336-9

147. Brown MA, Thom JV, Orth GL, Cova P, Juarez J. Food poisoning involving zinc contamination. Arch Environ Health. 1964;8:657660. doi:10.1080/00039896.1964.10663736

148. Fosmire GJ. Zinc toxicity. Am J Clin Nutr. 1990;51(2):225-227. doi:10.1093/ajen/51.2.225 
149. Murakami Y, Koyabu T, Kawashima A, et al. Zinc supplementation prevents the increase of transaminase in chronic hepatitis $\mathrm{C}$ patients during combination therapy with pegylated interferonalpha-2b and ribavirin. J Nutr Sci Vitaminol (Tokyo). 2007;53 (3):213-218. doi:10.3177/jnsv.53.213

150. Raza N, Khan DA. Zinc deficiency in patients with persistent viral warts. J Coll Physicians Surg Pak. 2010;20(2):83-86.

151. Simonart T, de Maertelaer V. Systemic treatments for cutaneous warts: a systematic review. J Dermatolog Treat. 2012;23(1):7277. doi:10.3109/09546634.2010.500324

152. Bhutta ZA, Black RE, Brown KH, et al. Prevention of diarrhea and pneumonia by zinc supplementation in children in developing countries: pooled analysis of randomized controlled trials. Zinc Investigators' Collaborative Group. J Pediatr. 1999;135(6):689697. doi:10.1016/s0022-3476(99)70086-7

153. Field CJ, Johnson IR, Schley PD. Nutrients and their role in host resistance to infection. J Leukoc Biol. 2002;71(1):16-32.

154. Overbeck S, Uciechowski P, Ackland ML, Ford D, Rink L. Intracellular zinc homeostasis in leukocyte subsets is regulated by different expression of zinc exporters ZnT-1 to ZnT-9. J Leukoc Biol. 2008;83(2):368-380. doi:10.1189/jlb.0307148

155. Prasad AS. Zinc: role in immunity, oxidative stress, and chronic inflammation. Curr Opin Clin Nutr Metab Care. 2009;12(6):646652. doi:10.1097/MCO.0b013e3283312956

156. Fraker PJ, King LE, Laakko T, Vollmer TL. The dynamic link between the integrity of the immune system and zinc status. J Nutr. 2000;130 (5SSuppl):1399S-406S. doi:10.1093/jn/130.5.1399S

157. Prasad AS, Meftah S, Abdallah J, et al. Serum thymulin in human zinc deficiency. J Clin Invest. 1988;82(4):1202-1210. doi:10.11 72/JCI113717

158. Sprietsma JE. Modern diets and diseases: NO-zinc balance. Under Th1, zinc, and nitrogen monoxide (NO) collectively protect against viruses, AIDS, autoimmunity, diabetes, allergies, asthma, infectious diseases, atherosclerosis, and cancer. Med Hypotheses. 1999;53(1):6-16. doi:10.1054/mehy.1999. 0867

159. Walker CLF, Rudan I, Liu L, et al. Global burden of childhood pneumonia and diarrhea. Lancet. 2013;381(9875):1405-1416. doi:10.1016/S0140-6736(13)60222-6

160. Bailey RL, West KP Jr, Black RE. The epidemiology of global micronutrient deficiencies. Ann Nutr Metab. 2015;66(Suppl 2):22-33. doi:10.1159/000371618

161. Shankar AH, Prasad AS. Zinc and immune function: the biological basis of altered resistance to infection. Am J Clin Nutr. 1998;68(2Suppl):447S-463S. doi:10.1093/ajen/68.2.447S

162. DePasquale-Jardieu P, Fraker PJ. Interference in the development of a secondary immune response in mice by zinc deprivation: persistence of effects. $J$ Nutr. 1984;114(10):1762-1769. doi:10.1093/jn/114.10.1762

163. Fraker PJ, Caruso R, Kierszenbaum F. Alteration of the immune and nutritional status of mice by synergy between zinc deficiency and infection with Trypanosoma cruzi. J Nutr. 1982;112(6):12241229. doi:10.1093/jn/112.6.1224

164. Yasuda H, Tsutsui T. Infants, and elderlies are susceptible to zinc deficiency. Sci Rep. 2016;6:21850. doi:10.1038/srep21850

165. Kluge HHP, Wickramasinghe K, Rippin HL, et al. Prevention and control of non-communicable diseases the COVID-19 response. Lancet. 2020;395(10238):1678-1680. doi:10.1016/S0140-6736 (20)31067-9

166. Chabosseau P, Rutter GA. Zinc, and diabetes. Arch Biochem Biophys. 2016;611:79-85. doi:10.1016/j.abb.2016.05.022

167. Fukunaka A, Fujitani Y. Role of zinc homeostasis in the pathogenesis of diabetes and obesity. Int J Mol Sci. 2018;19(2):476. doi:10.3390/ijms 19020476
168. Wang S, Gu J, Xu Z, et al. Zinc rescues obesity-induced cardiac hypertrophy via stimulating metallothionein to suppress oxidative stress-activated BCL10/CARD9/p38 MAPK pathway. J Cell Mol Med. 2017;21(6):1182-1192. doi:10.1111/jcmm.13050

169. Singh M, Das RR. Zinc for the common cold. Cochrane Database Syst Rev. 2013;6:CD001364. doi:10.1002/14651858. CD001364.pub4

170. Kumar S, Awasthi S, Jain A, Srivastava RC. Blood zinc levels in children hospitalized with severe pneumonia: a case-control study. Indian Pediatr. 2004;41(5):486-491.

171. Shakur MS, Malek MA, Bano N, Islam K. Zinc status in wellnourished Bangladeshi children suffering from acute lower respiratory infection. Indian Pediatr. 2004;41(5):478-481.

172. Ibraheem RM, Johnson AB, Abdulkarim AA, Biliaminu SA. Serum zinc levels in hospitalized children with acute lower respiratory infections in the north-central region of Nigeria. Afr Health Sci. 2014;14(1):136-142. doi:10.4314/ahs.v14i1.21

173. Eby GA. Zinc ion availability-the determinant of efficacy in zinc lozenge treatment of common colds. J Antimicrob Chemother. 1997;40(4):483-493. doi:10.1093/oxfordjournals.jac.a020864

174. Hemilä H. Common cold treatment using zinc. JAMA. 2015;314 (7):730. doi:10.1001/jama.2015.8174

175. Eby GA 3rd. Zinc lozenges as cure for the common cold-a review and hypothesis. Med Hypotheses. 2010;74(3):482-492. doi:10.1016/j.mehy.2009.10.017

176. Hemilä H. Zinc lozenges may shorten the duration of colds: a systematic review. Open Respir Med J. 2011;5:51-58. doi:10.2174/1874306401105010051

177. Abd-Elsalam S, Soliman S, Esmail ES, et al. Do zinc supplements enhance the clinical efficacy of hydroxychloroquine? A randomized, multicenter trial. Biol Trace Elem Res. 2020:1-5. doi:10.1007/s12011-020-02512-1.

178. Arentz S, Hunter J, Yang G, et al. Zinc for the prevention and treatment of SARS-CoV-2 and other acute viral respiratory infections: a rapid review. Adv Integr Med. 2020;7(4):252-260. doi:10.1016/j.aimed.2020.07.009

179. Alexander J, Tinkov A, Strand TA, Alehagen U, Skalny A, Aaseth J. Early nutritional interventions with zinc, selenium, and vitamin $\mathrm{D}$ for raising anti-viral resistance against progressive COVID-19. Nutrients. 2020;12(8):2358. doi:10.3390/ nu 12082358

180. Name JJ, Souza ACR, Vasconcelos AR, Prado PS, Pereira CPM. Zinc, vitamin D, and vitamin C: perspectives for COVID-19 with a focus on physical tissue barrier integrity. Front Nutr. 2020;7:606398. doi:10.3389/fnut.2020.606398

181. Rondanelli M, Miccono A, Lamburghini S, et al. Self-care for common colds: the pivotal role of vitamin $\mathrm{D}$, vitamin $\mathrm{C}$, zinc, and echinacea in three main immune interactive clusters (Physical barriers, innate and adaptive immunity) involved during an episode of common colds-practical advice on dosages and on the time to take these nutrients/botanicals in order to prevent or treat common colds. Evid Based Complement Alternat Med. 2018;2018:5813095. doi:10.1155/2018/5813095

182. Carlucci PM, Ahuja T, Petrilli C, Rajagopalan H, Jones S, Rahimian J. Zinc sulfate, in combination with a zinc ionophore, may improve outcomes in hospitalized COVID-19 patients. $J$ Med Microbiol. 2020;69(10):1228-1234. doi:10.1099/jmm. 0.001250

183. Agnew UM, Slesinger TL. Zinc toxicity. In: StatPearls [Internet]. Treasure Island (FL): StatPearls Publishing; 2020. PMID: 32119435.

184. Sheqwara J, Alkhatib Y. Sideroblastic anemia secondary to zinc toxicity. Blood. 2013;122(3):311. doi:10.1182/blood-2012-12469239 
185. Appenzeller-Herzog C, Mathes T, Heeres MLS, Weiss KH, Houwen RHJ, Ewald H. Comparative effectiveness of common therapies for Wilson disease: a systematic review and meta-analysis of controlled studies. Liver Int. 2019;39(11):2136-2152. doi:10.1111/liv.14179

186. Gummin DD, Mowry JB, Spyker DA, Brooks DE, Osterthaler KM, Banner W. 2017 Annual Report of the American Association of Poison Control Centers' National Poison Data System (NPDS): 35th Annual Report. Clin Toxicol (Phila). 2018;56(12):12131415. doi:10.1080/15563650.2018.1533727

187. McPherson SW, Keunen JE, Bird AC, Chew EY, van Kuijk FJ. Investigate oral zinc as a prophylactic treatment for those at risk for COVID-19. Am J Ophthalmol. 2020;216:A5-A6. doi:10.10 16/j.ajo.2020.04.028

188. Dabbagh-Bazarbachi H, Clergeaud G, Quesada IM, Ortiz M, O’Sullivan CK, Fernández-Larrea JB. Zinc ionophore activity of quercetin and epigallocatechin-gallate: from Hepa 1-6 cells to a liposome model. J Agric Food Chem. 2014;62(32):8085-8093. doi:10.1021/jf5014633

189. Hecel A, Ostrowska M, Stokowa-Sołtys K, et al. Zinc(II)-the overlooked éminence grise of chloroquine's fight against COVID-19? Pharmaceuticals (Basel). 2020;13(9):228. doi:10.33 90/ph13090228

190. Krenn BM, Gaudernak E, Holzer B, Lanke K, Van Kuppeveld FJ, Seipelt J. Antiviral activity of the zinc ionophores pyrithione and hinokitiol against picornavirus infections. J Virol. 2009;83(1):5864. doi:10.1128/JVI.01543-08

191. Pawar A, Pal A. Molecular and functional resemblance of dexamethasone and quercetin: a paradigm worth exploring in dexamethasone-nonresponsive COVID-19 patients. Phytother Res. 2020;34(12):3085-3088. doi:10.1002/ptr.6886

192. Brewer J, Gomez Marti JL, Brufsky A. Potential interventions for SARS-CoV-2 infections: zinc showing promise. J Med Virol. 2020. doi: $10.1002 / \mathrm{jmv} .26523$

193. Pal A, Pawar A, Goswami K, Sharma P, Prasad R. Hydroxychloroquine, and Covid-19: a cellular and molecular biology based update. Indian J Clin Biochem. 2020;35(3):274284. doi:10.1007/s12291-020-00900-x

194. Schrezenmeier E, Dörner T. Mechanisms of action of hydroxychloroquine and chloroquine: implications for rheumatology. Nat Rev Rheumatol. 2020;16(3):155-166. doi:10.1038/s41584-0200372-x

195. Conway DJ. Paths to a malaria vaccine illuminated by parasite genomics. Trends Genet. 2015;31(2):97-107. doi:10.1016/j. tig.2014.12.005

196. Karunamoorthi K. Malaria vaccine: a future hope to curtail the global malaria burden. Int J Prev Med. 2014;5(5):529-538. PMID: 24932383; PMCID: PMC4050672.

197. de Beer TA, Wells GA, Burger PB, et al. Antimalarial drug discovery: in silico structural biology and rational drug design. Infect Disord Drug Targets. 2009;9(3):304-318. doi:10.2174/ 1871526510909030304

198. Vedadi M, Lew J, Artz J, et al. Genome-scale protein expression and structural biology of Plasmodium falciparum and related Apicomplexan organisms. Mol Biochem Parasitol. 2007;151 (1):100-110. doi:10.1016/j.molbiopara.2006.10.011

199. Flannery EL, Chatterjee AK, Winzeler EA. Antimalarial drug discovery - approaches and progress towards new medicines. Nat Rev Microbiol. 2013;11(12):849-862. doi:10.1038/nrmicro3138

200. Ridley RG. Medical need, scientific opportunity, and the drive for antimalarial drugs. Nature. 2002;415(6872):686-693. doi:10.10 $38 / 415686 a$

201. Mitchell W. Natural products from synthetic biology. Curr Opin Chem Biol. 2011;15(4):505-515. doi:10.1016/j.cbpa.2011.05.017
202. Paddon CJ, Westfall PJ, Pitera DJ, et al. High-level semi-synthetic production of the potent antimalarial artemisinin. Nature. 2013;496(7446):528-532. doi:10.1038/nature12051

203. Buckee CO, Wesolowski A, Eagle NN, Hansen E, Snow RW. Mobile phones and malaria: modeling human and parasite travel. Travel Med Infect Dis. 2013;11(1):15-22. doi:10.1016/j.tmaid.20 12.12.003

204. Hay SI, George DB, Moyes CL, Brownstein JS. Big data opportunities for global infectious disease surveillance. PLoS Med. 2013;10(4):e1001413. doi:10.1371/journal.pmed.1001413

205. Pahan P, Pahan K. Smooth or risky revisit of an old malaria drug for COVID-19? J Neuroimmune Pharmacol. 2020;15(2):174180. doi:10.1007/s11481-020-09923-w

206. Yang ZY, Huang Y, Ganesh L, et al. pH-dependent entry of severe acute respiratory syndrome coronavirus is mediated by the spike glycoprotein and enhanced by dendritic cell transfer through DCSIGN. J Virol. 2004;78(11):5642-5650. doi:10.1128/JVI.78.11.56 42-5650.2004

207. Mehta P, McAuley DF, Brown M, et al.; HLH Across Speciality Collaboration, UK. COVID-19: consider cytokine storm syndromes and immunosuppression. Lancet. 2020;395 (10229):1033-1034. doi:10.1016/S0140-6736(20)30628-0.

208. Huang C, Wang Y, Li X, et al. Clinical features of patients infected with 2019 novel coronavirus in Wuhan, China. Lancet. 2020;395(10223):497-506. doi:10.1016/S0140-6736(20)30183-5

209. Chen G, Wu D, Guo W, et al. Clinical and immunological features of severe and moderate coronavirus disease 2019. J Clin Invest. 2020;130(5):2620-2629. doi:10.1172/JCI137244

210. Kim ML, Martin WJ, Minigo G, et al. Dysregulated IL-1 $\beta$-GMCSF axis in acute rheumatic fever that is limited by hydroxychloroquine. Circulation. 2018;138(23):2648-2661. doi:10.1161/ CIRCULATIONAHA.118.033891

211. Batún-Garrido JAJ, Salas-Magaña M, Juárez-Rojop IE. Association between leptin and IL-6 concentrations with cardiovascular risk in patients with rheumatoid arthritis. Clin Rheumatol. 2018;37(3):631-637. doi:10.1007/s10067-017-3897-x

212. Watanabe T, Jono H, Han J, Lim DJ, Li JD. Synergistic activation of NF-kappaB by non-typeable Haemophilus influenzae and tumor necrosis factor-alpha. Proc Natl Acad Sci USA. 2004;101 (10):3563-3568. doi:10.1073/pnas.0400557101

213. Saha RN, Pahan K. Signals for the induction of nitric oxide synthase in astrocytes. Neurochem Int. 2006;49(2):154-163. doi:10.1016/j.neuint.2006.04.007

214. Saha RN, Pahan K. Regulation of inducible nitric oxide synthase gene in glial cells. Antioxid Redox Signal. 2006;8(5-6):929-947. doi:10.1089/ars.2006.8.929

215. Liang N, Zhong Y, Zhou J, et al. Immunosuppressive effects of hydroxychloroquine and artemisinin combination therapy via the nuclear factor- $\mathrm{\kappa B}$ signaling pathway in lupus nephritis mice. Exp Ther Med. 2018;15(3):2436-2442. doi:10.3892/etm.2018.5708

216. Kircheis R, Haasbach E, Lueftenegger D, Heyken WT, Ocker M, Planz O. NF-kB pathway as a potential target for treatment of critical stage COVID-19 patients. Front Immunol. 2020; 11:598444. doi:10.3389/fimmu.2020.598444

217. Gasparello J, Finotti A, Gambari R. Tackling the COVID-19 "cytokine storm" with microRNA mimics directly targeting the 3'UTR of pro-inflammatory mRNAs. Med Hypotheses. 2020;146:110415. doi:10.1016/j.mehy.2020.110415

218. Zizzo G, Cohen PL. Imperfect storm: is interleukin-33 the Achilles heel of COVID-19? Lancet Rheumatol. 2020;2(12): e779-e790. doi:10.1016/S2665-9913(20)30340-4

219. Mahallawi WH, Khabour OF, Zhang Q, Makhdoum HM, Suliman BA. MERS-CoV infection in humans is associated with a proinflammatory Th1 and Th17 cytokine profile. Cytokine. 2018;104:8-13. doi:10.1016/j.cyto.2018.01.025 
220. Costela-Ruiz VJ, Illescas-Montes R, Puerta-Puerta JM, Ruiz C, Melguizo-Rodríguez L. SARS-CoV-2 infection: the role of cytokines in COVID-19 disease. Cytokine Growth Factor Rev. 2020;54:62-75. doi:10.1016/j.cytogfr.2020.06.001

221. Chen T, Wu D, Chen $\mathrm{H}$, et al. Clinical characteristics of 113 deceased patients with coronavirus disease 2019: retrospective study. BMJ. 2020;368:m1091. doi:10.1136/bmj.m1091

222. Leisman DE, Ronner L, Pinotti R, et al. Cytokine elevation in severe and critical COVID-19: a rapid systematic review, metaanalysis, and comparison with other inflammatory syndromes. Lancet Respir Med. 2020;8(12):1233-1244. doi:10.1016/S22132600(20)30404-5

223. Tisoncik JR, Korth MJ, Simmons CP, Farrar J, Martin TR, Katze MG. Into the eye of the cytokine storm. Microbiol Mol Biol Rev. 2012;76(1):16-32. doi:10.1128/MMBR.05015-11

224. Wu D, Yang XO. TH17 responses in cytokine storm of COVID-19: an emerging target of JAK2 inhibitor Fedratinib. J Microbiol Immunol Infect. 2020;53(3):368-370. doi:10.1016/j.jmii.2020.03.005

225. De Biasi S, Meschiari M, Gibellini L, et al. Marked T cell activation, senescence, exhaustion and skewing towards TH17 in patients with COVID-19 pneumonia. Nat Commun. 2020;11 (1):3434. doi:10.1038/s41467-020-17292-4

226. Parackova Z, Bloomfield M, Klocperk A, Sediva A. Neutrophils mediate Th17 promotion in COVID-19 patients. J Leukoc Biol. 2020. doi:10.1002/JLB.4COVCRA0820-481RRR

227. Xu Z, Shi L, Wang Y, et al. Pathological findings of COVID-19 associated with acute respiratory distress syndrome. Lancet Respir Med. 2020;8(4):420-422. doi:10.1016/S2213-2600(20)30076-X

228. Zhang YY, Li BR, Ning BT. The comparative immunological characteristics of SARS-CoV, MERS-CoV, and SARS-CoV-2 coronavirus infections. Front Immunol. 2020;11:2033. doi:10. 3389/fimmu.2020.02033

229. Kjeldsen K. Hypokalemia and sudden cardiac death. Exp Clin Cardiol. 2010;15(4):e96-9.

230. Bielecka-Dabrowa A, Mikhailidis DP, Jones L, Rysz J, Aronow WS, Banach M. The meaning of hypokalemia in heart failure. Int J Cardiol. 2012;158(1):12-17. doi:10.1016/ j.ijcard.2011.06.121

231. Skogestad J, Aronsen JM. Hypokalemia-induced arrhythmias and heart failure: new insights and implications for therapy. Front Physiol. 2018;9:1500. doi:10.3389/fphys.2018.01500

232. Chen N, Zhou M, Dong X, et al. Epidemiological and clinical characteristics of 99 cases of 2019 novel coronavirus pneumonia in Wuhan, China: a descriptive study. Lancet. 2020;395 (10223):507-513. doi:10.1016/S0140-6736(20)30211-7

233. Guo T, Fan Y, Chen M, et al. Cardiovascular implications of fatal outcomes of patients with coronavirus disease 2019 (COVID-19). JAMA Cardiol. 2020;5(7):811-818. doi:10.1001/jamacardio.20 20.1017

234. Wang D, $\mathrm{Hu} \mathrm{B}, \mathrm{Hu} \mathrm{C}$, et al. Clinical characteristics of 138 hospitalized patients with 2019 novel coronavirus-infected pneumonia in Wuhan, China. JAMA. 2020;323(11):1061-1069. doi:10.1001/jama.2020.1585

235. Zhang DD, Gao ZX, Vio CP, et al. Bradykinin stimulates renal $\mathrm{Na}$ + and $\mathrm{K}+$ excretion by inhibiting the $\mathrm{K}+$ channel (Kir4.1) in the distal convoluted tubule. Hypertension. 2018;72(2):361-369. doi:10.1161/HYPERTENSIONAHA.118.11070

236. Ma L, Song K, Huang Y. Coronavirus disease-2019 (COVID19), and cardiovascular complications. J Cardiothorac Vasc Anesth. 2020;S1053-0770(20)30400-6. doi:10.1053/j. jvca.2020.04.041

237. Gopinathannair R, Merchant FM, Lakkireddy DR, et al. COVID-19 and cardiac arrhythmias: a global perspective on arrhythmia characteristics and management strategies. J Interv Card Electrophysiol. 2020;59(2):329-336. doi:10.1007/s10840-020-00789-9
238. Garvin MR, Alvarez C, Miller JI, et al. A mechanistic model and therapeutic interventions for COVID-19 involving a RASmediated bradykinin storm. Elife. 2020;9:e59177. doi:10.7554/ eLife. 59177

239. van de Veerdonk FL, Netea MG, van Deuren M, et al. Kallikreinkinin blockade in patients with COVID-19 to prevent acute respiratory distress syndrome. Elife. 2020;9:e57555. doi:10.75 54/eLife. 57555

240. Offringa A, Montijn R, Singh S, Paul M, Pinto YM, PintoSietsma SJ. The mechanistic overview of SARS-CoV-2 using angiotensin-converting enzyme 2 to enter the cell for replication: possible treatment options related to the renin-angiotensin system. Eur Heart J Cardiovasc Pharmacother. 2020;6(5):317-325. doi:10.1093/ehjcvp/pvaa053

241. Damasceno IZ, Melo KR, Nascimento FD, et al. Bradykinin release avoids high molecular weight kininogen endocytosis. PLoS One. 2015;10(3):e0121721. doi:10.1371/journal.pone.0121 721

242. Kaplan AP, Joseph K, Silverberg M. Pathways for bradykinin formation and inflammatory disease. J Allergy Clin Immunol. 2002;109(2):195-209. doi:10.1067/mai.2002.121316

243. Kalinska M, Meyer-Hoffert U, Kantyka T, Potempa J. Kallikreins - the melting pot of activity and function. Biochimie. 2016;122:270-282. doi:10.1016/j.biochi.2015.09.023

244. Koumandou VL, Scorilas A. Evolution of the plasma and tissue kallikreins, and their alternative splicing isoforms. PLoS One. 2013;8(7):e68074. doi:10.1371/journal.pone.0068074

245. Sparks MA, Crowley SD, Gurley SB, Mirotsou M, Coffman TM. Classical renin-angiotensin system in kidney physiology. Compr Physiol. 2014;4(3):1201-1228. doi:10.1002/cphy.c130040

246. Givertz MM. Manipulation of the renin-angiotensin system. Circulation. 2001;104(5):E14-8. doi:10.1161/hc3001.094733

247. Debela M, Magdolen V, Grimminger V, et al. Crystal structures of human tissue kallikrein 4: activity modulation by a specific zincbinding site. J Mol Biol. 2006;362(5):1094-1107. doi:10.1016/j. jmb.2006.08.003

248. Debela M, Goettig P, Magdolen V, Huber R, Schechter NM, Bode W. Structural basis of the zinc inhibition of human tissue kallikrein 5. J Mol Biol. 2007;373(4):1017-1031. doi:10.1016/j. jmb.2007.08.042

249. Debela M, Hess P, Magdolen V, et al. Chymotryptic specificity determinants in the $1.0 \mathrm{~A}$ structure of the zinc-inhibited human tissue kallikrein 7. Proc Natl Acad Sci USA. 2007;104 (41):16086-16091. doi:10.1073/pnas.0707811104

250. Skala W, Utzschneider DT, Magdolen V, et al. Structure-function analyses of human kallikrein-related peptidase 2 establish the 99loop as master regulator of activity. J Biol Chem. 2014;289 (49):34267-34283. doi:10.1074/jbc.M114.598201

251. Goettig P, Magdolen V, Brandstetter H. Natural and synthetic inhibitors of kallikrein-related peptidases (KLKs). Biochimie. 2010;92(11):1546-1567. doi:10.1016/j.biochi.2010.06.022

252. Pal A, Squitti R, Picozza M, et al. Zinc and COVID-19: basis of current clinical trials. Biol Trace Elem Res. 2020:1-11. doi:10.1007/s12011-020-02437-9.

253. Razzaque MS. COVID-19 pandemic: can boosting immune responses by maintaining adequate nutritional balance reduce viral insults? Adv Hum Biol. 2020;10(3):99-102. doi:10.4103/ AIHB.AIHB_75_20

254. Calder PC, Carr AC, Gombart AF, Eggersdorfer M. Optimal nutritional status for a well-functioning immune system is an important factor to protect against viral infections. Nutrients. 2020;12(4):1181. doi:10.3390/nu12041181

255. Chaari A, Bendriss G, Zakaria D, McVeigh C. Importance of dietary changes during the coronavirus pandemic: how to upgrade your immune response. Front Public Health. 2020;8:476. doi:10.3389/fpubh.2020.00476 
256. Gombart AF, Pierre A, Maggini S. A review of micronutrients and the immune system-working in harmony to reduce the risk of infection. Nutrients. 2020;12(1):236. doi:10.3390/nu120 10236

257. Guillin OM, Vindry C, Ohlmann T, Chavatte L. Selenium, selenoproteins, and viral infection. Nutrients. 2019;11(9):2101. doi:10.3390/nu11092101

258. Taheri M, Bahrami A, Habibi P, Nouri F. A review on the serum electrolytes and trace elements role in the pathophysiology of COVID-19. Biol Trace Elem Res. 2020;1-7. doi:10.1007/ s12011-020-02377-4

259. Zhang J, Taylor EW, Bennett K, Saad R, Rayman MP. Association between regional selenium status and reported outcome of COVID-19 cases in China. Am J Clin Nutr. 2020;111 (6):1297-1299. doi:10.1093/ajcn/nqaa095

260. Baum MK, Shor-Posner G, Lai S, et al. High risk of HIV-related mortality is associated with selenium deficiency. J Acquir Immune Defic Syndr Hum Retrovirol. 1997;15(5):370374. PMID: 9342257. doi:10.1097/00042560-199708150-00 007

261. Broome CS, McArdle F, Kyle JA, et al. An increase in selenium intake improves immune function and poliovirus handling in adults with marginal selenium status. Am J Clin Nutr. 2004;80 (1):154-162. doi:10.1093/ajen/80.1.154

262. Hou JC. Inhibitory effect of selenite and other antioxidants on complement-mediated tissue injury in patients with epidemic hemorrhagic fever. Biol Trace Elem Res. 1997;56(1):125-130. doi:10.1007/BF02778988

263. Bonham M, O'Connor JM, Hannigan BM, Strain JJ. The immune system as a physiological indicator of marginal copper status? $\mathrm{Br}$ $J$ Nutr. 2002;87(5):393-403. PMID: 12010579. doi:10.1079/ BJNBJN2002558

264. Hopkins RG, Failla ML. Copper deficiency reduces interleukin-2 (IL-2) production and IL-2 mRNA in human T-lymphocytes. $J$ Nutr. 1997;127(2):257-262. doi:10.1093/jn/127.2.257

265. Mao S, Zhang A, Huang S. Meta-analysis of $\mathrm{Zn}, \mathrm{Cu}$, and $\mathrm{Fe}$ in the hair of Chinese children with recurrent respiratory tract infection. Scand J Clin Lab Invest. 2014;74(7):561-567. doi:10.3109/ 00365513.2014 .921323

266. Vyas D, Chandra RK. Thymic factor activity, lymphocyte stimulation response, and antibody-producing cells in copper deficiency. Nutr Res. 1983;3(3):343-349. doi:10.1016/S0271-5317(83)80084-0

267. Calder PC. Nutrition, immunity, and COVID-19. BMJ Nutr Prev Health. 2020;3(1):74-92. doi:10.1136/bmjnph-2020-000085

268. Iddir M, Brito A, Dingeo G, et al. Strengthening the immune system and reducing inflammation and oxidative stress through diet and nutrition: considerations during the COVID-19 crisis. Nutrients. 2020;12(6):1562. doi:10.3390/nu12061562

269. Liu W, Zhang S, Nekhai S, Liu S. Depriving iron supply to the virus represents a promising adjuvant therapeutic against viral survival. Curr Clin Microbiol Rep. 2020;1-7. doi:10.1007/ s40588-020-00140-w

270. Fernández-Quintela A, Milton-Laskibar I, Trepiana J, et al. Key aspects in nutritional management of COVID-19 patients. J Clin Med. 2020;9(8):2589. doi:10.3390/jcm9082589

271. Joseph N, Nelliyanil M, Rai S, et al. Fast-food consumption pattern and its association with overweight among high school boys in Mangalore City of Southern India. J Clin Diagn Res. 2015;9(5):LC13-LC17. doi:10.7860/JCDR/2015/13103.5969

272. Abiri B, Vafa M. Micronutrients that affect immunosenescence. Adv Exp Med Biol. 2020;1260:13-31. doi:10.1007/978-3-03042667-5 2
273. Pae M, Wu D. Nutritional modulation of age-related changes in the immune system and risk of infection. Nutr Res. 2017;41:1435. doi:10.1016/j.nutres.2017.02.001

274. Maggini S, Pierre A, Calder PC. Immune function and micronutrient requirements change over the life course. Nutrients. 2018;10(10):1531. doi:10.3390/nu10101531

275. Di Renzo L, Gualtieri P, Pivari F, et al. COVID-19: is there a role for immunonutrition in obese patient? J Transl Med. 2020;18 (1):415. doi:10.1186/s12967-020-02594-4

276. Darnton-Hill I. Public health aspects in the prevention and control of vitamin deficiencies. Curr Dev Nutr. 2019;3(9):nzz075. doi:10.1093/cdn/nzz075

277. Fantacone ML, Lowry MB, Uesugi SL, et al. The effect of a multivitamin and mineral supplement on immune function in healthy older adults: a double-blind, randomized, controlled trial. Nutrients. 2020;12(8):2447. doi:10.3390/nu12082447

278. Zabetakis I, Lordan R, Norton C, Tsoupras A. COVID-19: the inflammation link and the role of nutrition in potential mitigation. Nutrients. 2020;12(5):1466. doi:10.3390/nu12051466

279. Galmés S, Serra F, Palou A. Current state of evidence: influence of nutritional and nutrigenetic factors on immunity in the COVID-19 pandemic framework. Nutrients. 2020;12(9):2738. doi:10.3390/nu12092738

280. Junaid K, Ejaz H, Abdalla AE, et al. Effective immune functions of micronutrients against SARS-CoV-2. Nutrients. 2020;12 (10):2992. doi:10.3390/nu12102992

281. Dalan R, Bornstein SR, El-Armouche A, et al. The ACE-2 in COVID-19: foe or friend? Horm Metab Res. 2020;52(5):257-263. doi:10.1055/a-1155-0501

282. Rahman MT, Idid SZ. Can Zn be a critical element in COVID-19 treatment? Biol Trace Elem Res. 2020;1-9. doi:10.1007/s12011020-02194-9

283. Muzzioli M, Stecconi R, Donnini A, Re F, Provinciali M. Zinc improves the development of human $\mathrm{CD} 34+$ cell progenitors towards Natural Killer cells and induces the expression of GATA-3 transcription factor. Int J Biochem Cell Biol. 2007;39 (5):955-965. doi:10.1016/j.biocel.2007.01.011

284. Prager I, Liesche $\mathrm{C}$, van Ooijen $\mathrm{H}$, et al. NK cells switch from granzyme B to death receptor-mediated cytotoxicity during serial killing. J Exp Med. 2019;216(9):2113-2127. doi:10.1084/ jem.20181454

285. Wang G. Human antimicrobial peptides and proteins. Pharmaceuticals (Basel). 2014;7(5):545-594. doi:10.3390/ ph7050545

286. Negishi H, Taniguchi T, Yanai H. The interferon (IFN) class of cytokines and the IFN regulatory factor (IRF) transcription factor family. Cold Spring Harb Perspect Biol. 2018;10(11):a028423. doi:10.1101/cshperspect.a028423

287. World Bank. Global economic prospects, June 2020. Washington, DC: World Bank. (C) World Bank. License: CC BY 3.0 IGO; 2020 Available from: https://openknowledge.worldbank.org/handle/ 10986/33748. Accessed November 26, 2020.

288. Centers for Disease Control and Prevention. Principles of epidemiology in public health practice, third edition an introduction to applied epidemiology and biostatistics; 2011. Available from: https:/www.cdc.gov/csels/dsepd/ss1978/lesson1/section11.html. Accessed November 26, 2020.

289. Institute of Medicine (US) Forum on Microbial Threats. Ethical and legal considerations in mitigating pandemic disease: workshop summary. Washington (DC): National Academies Press (US); 2007. 3: Strategies for Disease Containment. Available from: https://www.ncbi.nlm.nih.gov/books/ NBK54163/. Accessed November 27, 2020. 
290. Madhav N, Oppenheim B, Gallivan M, et al. Pandemics: risks, impacts, and mitigation. In: Jamison DT, Gelband H, Horton S, et al. editors. Disease Control Priorities: Improving Health and Reducing Poverty. 3rd ed. Washington (DC): The International Bank for Reconstruction and Development/The World Bank; November 27, 2017. Chapter 17. doi:10.1596/978-1-4648-05271_ch17

291. World O Meter. COVID-19 coronavirus pandemic. Coronavirus; 2020. Available from: https://www.worldometers.info/corona virus/?utm_campaign=homeAdvegas 1 ?\%22. Accessed January $19,2021$.

292. The World Bank. COVID-19 to plunge global economy into worst recession since World War II; 2020. Available from: https://www.worldbank.org/en/news/press-release/2020/06/08/ covid-19-to-plunge-global-economy-into-worst-recession-sinceworld-war-ii. Accessed November 28, 2020.

293. Zumbrun J World bank sees 5.2\% decline in global economy in 2020 from coronavirus. The Wall Street Journal; 2020. Available from: https://www.wsj.com/articles/world-bank-sees-5-2-declinein-global-economy-in-2020-from-coronavirus-11591631209. Accessed November 28, 2020.

294. The Lancet. India under COVID-19 lockdown. Lancet. 2020;395 (10233):1315. doi:10.1016/S0140-6736(20)30938-7.

295. Sjödin H, Wilder-Smith A, Osman S, Farooq Z, Rocklöv J. Only strict quarantine measures can curb the coronavirus disease (COVID-19) outbreak in Italy, 2020. Euro Surveill. 2020;25(13):2000280. doi:10.2807/1560-7917.ES.2020.25.13. 2000280

296. Garcia LP, Duarte E. Nonpharmaceutical interventions for tackling the COVID-19 epidemic in Brazil. Epidemiol Serv Saude. 2020;29(2):e2020222. doi:10.5123/S1679-49742020000200009

297. Burkert A, Loeb A Flattening the COVID-19 curves. Scientific American. Observations, opinion; 2020. Available from: https:// blogs.scientificamerican.com/observations/flattening-the-covid19-curves/. Accessed November 28, 2020.

298. Khoo EJ, Lantos JD. Lessons learned from the COVID-19 pandemic. Acta Paediatr. 2020;109(7):1323-1325. doi:10.1111/ apa.15307

299. Buck T, Arnold M, Chazan G, Cookson C Coronavirus declared a pandemic as fears of economic crisis mount. Financial Times; 2020. Available from: https://www.ft.com/content/d72f1e546396-11ea-b3f3-fe4680ea68b5. Accessed November 28, 2020.

300. The World Bank. Economic and social impacts of COVID-19: updates from the listening to Tajikistan survey; 2020. Available from: https:/www.worldbank.org/en/news/factsheet/2020/07/13/ economic-and-social-impacts-of-covid-19-update-from-listeningto-tajikistan. Accessed November 28, 2020.

301. Lim LL The socioeconomic impacts of COVID-19 in Malaysia: policy review and guidance for protecting the most vulnerable and supporting enterprises. International Laboure Organization; 2020. Available from: http://ilo.org/wcmsp5/groups/public/_asia/_ro-bangkok/documents/publication/wcms_751600.pdf. Accessed November 28, 2020.

302. Ghebreyesus TA. Strengthening our resolve for primary health care. Bull World Health Organ. 2020;98(11):726-726A. doi:10.2471/BLT.20.279489

303. White F. Primary health care and public health: foundations of universal health systems. Med Princ Pract. 2015;24(2):103-116. doi:10.1159/000370197

304. Rao M, Pilot E. The missing link-the role of primary care in global health. Glob Health Action. 2014;7:23693. doi:10.3402/ gha.v7.23693

305. Druetz T. Integrated primary health care in low- and middleincome countries: a double challenge. BMC Med Ethics. 2018;19(Suppl 1):48. doi:10.1186/s12910-018-0288-z
306. Global spending on health: a world in transition. Geneva: World Health Organization; 2019. Available from: https://apps.who.int/ iris/rest/bitstreams/1264564/retrieve. Accessed November 28, 2020.

307. World Health Organization and the United Nations Children's Fund (UNICEF). A vision for primary health care in the $21 \mathrm{st}$ century: towards universal health coverage and the sustainable development goals. Geneva; 2018. (WHO/HIS/SDS/2018.X). License: CC BY-NC-SA 3.0.IGO. Available from: https://www. who.int/docs/default-source/primary-health/vision.pdf. Accessed November 28, 2020.

308. World Health Organization. Primary health care; 2019. Available from: https://www.who.int/news-room/fact-sheets/detail/primaryhealth-care. Accessed November 28, 2020.

309. Langlois EV, McKenzie A, Schneider H, Mecaskey JW. Measures to strengthen primary healthcare systems in low- and middleincome countries. Bull World Health Organ. 2020;98(11):781791. doi:10.2471/BLT.20.252742

310. Lim WH, Wong WM. COVID-19: notes from the front line, Singapore's primary health care perspective. Ann Fam Med. 2020;18(3):259-261. doi:10.1370/afm.2539

311. Sarti TD, Lazarini WS, Fontenelle LF. Organization of Primary Health Care in pandemics: a rapid systematic review of the literature in times of COVID-19. medRxiv. 2020. doi:10.1101/ 2020.07.05.20146811

312. Bitton A, Fifield J, Ratcliffe $\mathrm{H}$, et al. Primary healthcare system performance in low-income and middle-income countries: a scoping review of the evidence from 2010 to 2017. BMJ Glob Health. 2019;4(Suppl 8):e001551. doi:10.1136/ bmjgh-2019-001551

313. Stenberg K, Hanssen O, Bertram M, et al. Guideposts for investment in primary health care and projected resource needs in 67 low-income and middle-income countries: a modeling study. Lancet Glob Health. 2019;7(11):e1500-e1510. doi:10.1016/ S2214-109X(19)30416-4

314. Fadlallah R, Bou-Karroum L, El-Jardali F, et al. Quality, safety and performance management in primary health care: from scoping review to research priority setting and implementation plan in the Eastern Mediterranean Region. BMJ Glob Health. 2019;4(Suppl 8):e001477. doi:10.1136/bmjgh2019-001477

315. Perry HB, Rassekh BM, Gupta S, Freeman PA. Comprehensive review of the evidence regarding the effectiveness of communitybased primary health care in improving maternal, neonatal, and child health: 7. shared characteristics of projects with evidence of long-term mortality impact. J Glob Health. 2017;7(1):010907. doi:10.7189/jogh.07.010907

316. Perry HB, Rassekh BM, Gupta S, Wilhelm J, Freeman PA. Comprehensive review of the evidence regarding the effectiveness of community-based primary health care in improving maternal, neonatal, and child health: 1. rationale, methods, and database description. J Glob Health. 2017;7(1):010901. doi:10.7189/ jogh.07.010901

317. Kruk ME, Gage AD, Arsenault C, et al. High-quality health systems in the Sustainable Development Goals era: time for a revolution. Lancet Glob Health. 2018;6(11):e1196-e1252. doi:10.1016/S2214-109X(18)30386-3

318. Chang BB, Chiu TY. Ready for a long fight against the COVID19 outbreak: an innovative model of tiered primary health care in Taiwan. BJGP Open. 2020;4(2):bjgpopen20X101068. doi:10.33 99/bjgpopen20X101068

319. Jan CF, Chiu TY, Chen CY, Guo FR, Lee MC. A 10-year review of health care reform on family practice integrated care projectTaiwan experience. Fam Pract. 2018;35(4):352-357. doi:10.10 93/fampra/cmx111 
320. Chang CM, Tan TW, Ho TC, Chen CC, Su TH, Lin CY. COVID-19: taiwan's epidemiological characteristics and public and hospital responses. Peer J. 2020;8:e9360. doi:10.7717/ peerj. 9360

321. Summers J, Cheng H-Y, Lin -H-H, et al. Potential lessons from the Taiwan and New Zealand health responses to the COVID-19 pandemic. Lancet Reg Health West Pacific. 2020. doi:10.1016/j. lanwpc.2020.100044

322. Rawaf S, Allen LN, Stigler FL, et al. Lessons on the COVID-19 pandemic, for and by primary care professionals worldwide. Eur $J$ Gen Pract. 2020;26(1):129-133. doi:10.1080/13814788. 2020.1820479

323. Palaniappan A, Dave U, Gosine B. Comparing South Korea and Italy's healthcare systems and initiatives to combat COVID-19. Rev Panam Salud Publica. 2020;44:e53. doi:10.26633/RPSP.2020.53

324. Oh J, Lee JK, Schwarz D, Ratcliffe HL, Markuns JF, Hirschhorn LR. National response to COVID-19 in the Republic of Korea and lessons learned for other countries. Health Syst Reform. 2020;6(1):e1753464. doi:10.1080/ 23288604.2020.1753464

325. Tan Z, Khoo DWS, Zeng LA, et al. Protecting health care workers in the front line: innovation in COVID-19 pandemic. $J$ Glob Health. 2020;10(1):010357. doi:10.7189/jogh.10.010357

326. Gai R, Tobe M. Managing healthcare delivery system to fight the COVID-19 epidemic: experience in Japan. Glob Health Res Policy. 2020;5:23. doi:10.1186/s41256-020-00149-0

327. Tashiro A, Shaw R. COVID-19 pandemic response in Japan: what is behind the initial flattening of the curve? Sustainability. 2020;12:5250. doi:10.3390/su12135250

328. Chen KT, Twu SJ, Chang HL, et al. SARS in Taiwan: an overview and lessons learned. Int $J$ Infect Dis. 2005;9(2):77-85. doi:10.1016/j.ijid.2004.04.015

329. Hsieh $\mathrm{YH}$, King $\mathrm{CC}$, Chen $\mathrm{CW}$, et al. Quarantine for SARS, Taiwan. Emerg Infect Dis. 2005;11(2):278-282. doi:10.3201/ eid1102.040190

330. Lin C, Braund WE, Auerbach J, et al. Policy decisions and use of information technology to fight COVID-19, Taiwan. Emerg Infect Dis. 2020;26(7):1506-1512. doi:10.3201/eid2607.200574

331. Su YF, Wu CH, Lee TF. Public health emergency response in Taiwan. Health Secur. 2017;15(2):137-143. doi:10.1089/hs.20 16.0108

332. Samad N, Sodunke TE, Banna HA, et al. Convalescent plasma therapy for management of COVID-19: perspectives and deployment in the current global pandemic. Risk Manag Healthc Policy. 2020;13:2707-2728. doi:10.2147/RMHP.S281388

333. Barron L What we can learn from Singapore, Taiwan, and Hong Kong about handling coronavirus. The Time; 2020. Available from: https://time.com/5802293/coronavirus-covid19-singaporehong-kong-taiwan/. Accessed November 28, 2020.

334. Sakamoto H, Rahman M, Nomura S, et al. Japan Health System Review. Vol. 8 No. 1. New Delhi: World Health Organization, Regional Office for Southeast Asia; 2018. Available from: https:// apps.who.int/iris/bitstream/handle/10665/259941/ 9789290226260 - e ng.pd f; j s e s s i o n id= 315E87830F83DC354350E24117FF59B5?sequence=1. Accessed November 29, 2020

335. Ikegami N, Yoo BK, Hashimoto H, et al. Japanese universal health coverage: evolution, achievements, and challenges. Lancet. 2011;378 (9796):1106-1115. doi:10.1016/S0140-6736(11)60828-3

336. Ikegami N. Japanese health care: low cost through regulated fees. Health Aff (Millwood). 1991;10(3):87-109. doi:10.1377/ hlthaff.10.3.87
337. Edmond C Elderly people make up a third of Japan's population and it's reshaping the country. World Economic Forum; 2019. Available from: https://www.weforum.org/agenda/2019/09/ elderly-oldest-population-world-japan/\#: :text=Japan $\% 20 \mathrm{has} \%$ 20the $\% 20$ highest $\% 20$ old,ages $\% 20$ of $\% 2020 \% 20$ and $\% 2064$. Accessed November 28, 2020.

338. Sakamoto H, Kita Y, Ezoe S How Japan's universal health care system led to COVID-19 Success. Tokyo report, the diplomat. 2020. Available from: https://thediplomat.com/2020/08/howjapans-universal-health-care-system-led-to-covid-19-success/. Accessed November 28, 2020.

339. Hamaguchi R, Negishi K, Higuchi M, Funato M, Kim J-H, Bitton A A regionalized public health model to combat COVID-19: lessons from Japan. Global health policy. Health affairs; 2020. Available from: https://www.healthaffairs.org/do/ 10.1377/hblog20200721.404992/full/. Accessed November 28, 2020.

340. Japan renews primary health care to promote healthy aging. Bull World Health Organ. 2018;96(7):448-449. doi:10.2471/ BLT.18.030718

341. Kato D, Ryu H, Matsumoto $\mathrm{T}$, et al. Building primary care in Japan: literature review. J Gen Fam Med. 2019;20(5):170-179. doi: $10.1002 /$ jgf 2.252

342. Oliver L Coronavirus: a pandemic in the age of inequality. World Economic Forum; 2019. Available from: https://www.weforum. org/agenda/2020/03/coronavirus-pandemic-inequality-amongworkers/. Accessed November 28, 2020.

343. Pringle D, Levitt C, Horsburgh ME, Wilson R, Whittaker MK. Interdisciplinary collaboration and primary health care reform. Can J Public Health. 2000;91(2):85-8, 97. doi:10.1007/ BF03404916

344. Morley L, Cashell A. Collaboration in health care. J Med Imaging Radiat Sci. 2017;48(2):207-216. doi:10.1016/j.jmir.2017.02.071

345. Jaruseviciene L, Liseckiene I, Valius L, Kontrimiene A, Jarusevicius G, Lapão LV. Teamwork in primary care: perspectives of general practitioners and community nurses in Lithuania. BMC Fam Pract. 2013;14:118. doi:10.1186/1471-2296-14-118

346. Chapa OR, Fuller SM, Hernandez LJ, McCray T. Competition versus collaboration in health care teams. Creat Nurs. 2017;23 (2):97-101. doi:10.1891/1078-4535.23.2.97

347. Razzaque MS. Implementation of antimicrobial stewardship to reduce antimicrobial drug resistance. Expert Rev Anti Infect Ther. 2020;1-4. doi:10.1080/14787210.2021.1840977

348. Pereno A, Eriksson D. A multi-stakeholder perspective on sustainable healthcare: from 2030 onwards. Futures. 2020;122:102605. doi:10.1016/j.futures.2020.102605

349. World Health Organization. Multisectoral and intersectoral action for improved health and well-being for all: mapping of the WHO European Region. Governance for a sustainable future: improving health and well-being for all. Final Report. WHO Regional Office for Europe, UN City, Marmorvej 51, DK-2100 Copenhagen Ø, Denmark; 2018. Available from: https://www.euro.who.int/ data/assets/pdf_file/0005/371435/multisectoral-report-h1720-eng. pdf. Accessed November 28, 2020.

350. Browne AJ, Varcoe CM, Wong ST, et al. Closing the health equity gap: evidence-based strategies for primary health care organizations. Int J Equity Health. 2012;11:59. doi:10.1186/ 1475-9276-11-59

351. Thomas SL, Wakerman J, Humphreys JS. Ensuring equity of access to primary health care in rural and remote Australia what core services should be locally available? Int $J$ Equity Health. 2015;14:111. doi:10.1186/s12939-015-0228-1 
352. Wakerman J, Sparrow L, Thomas SL, Humphreys JS, Jones M. Equitable resourcing of primary health care in remote communities in Australia's Northern Territory: a pilot study. BMC Fam Pract. 2017;18(1):75. doi:10.1186/s12875-017-0646-9

353. McGrail MR, Humphreys JS. Spatial access disparities to primary health care in rural and remote Australia. Geospat Health. 2015;10(2):358. doi:10.4081/gh.2015.358

354. Haque M, Islam T, Rahman NAA, et al. Strengthening primary health-care services to help prevent and control long-term (Chronic) non-communicable diseases in low- and middle-income countries. Risk Manag Healthc Policy. 2020;13:409-426. doi:10.2147/RMHP.S239074
355. Watkins DA, Jamison DT, Mills T, et al. Universal health coverage and essential packages of care. In: Jamison DT, Gelband H, Horton S, et al. editors. Disease Control Priorities: Improving Health and Reducing Poverty. 3rd ed. Washington (DC): The International Bank for Reconstruction and Development/The World Bank; November 27, 2017. doi:10.1596/978-1-46480527-1_ch3

\section{Publish your work in this journal}

The Journal of Inflammation Research is an international, peerreviewed open-access journal that welcomes laboratory and clinical findings on the molecular basis, cell biology and pharmacology of inflammation including original research, reviews, symposium reports, hypothesis formation and commentaries on: acute/chronic inflammation; mediators of inflammation; cellular processes; molecular mechanisms; pharmacology and novel anti-inflammatory drugs; clinical conditions involving inflammation. The manuscript management system is completely online and includes a very quick and fair peerreview system. Visit http://www.dovepress.com/testimonials.php to read real quotes from published authors. 